\title{
Shafts and Stars, Crafts and Sciences: The Making of a Jesuit Astronomer in the Habsburg Provinces
}

\section{$1 \quad$ A Regional Life World}

Almost in the geometric center of present-day Slovakia, nestled among the green hills south of the majestic peaks of the Tatra Mountains, scattered along the valley of the winding Hron (Granus, Garam) River, seven towns arose under the sovereignty of the kings of Hungary from the eleventh century onward. In the fifteenth century, they became collectively known as "the mining towns of Lower Hungary," an appellation based on their geographic position as compared to the Spiš (Szepes, Scepusium, Zips) mining region from the perspective of Vienna and Bratislava (Pozsony, Posonium, Pressburg), the seats of the imperial and royal governmental offices of Hungary in the early modern period. ${ }^{1}$ The protagonist of this book was born just outside one of these seven towns, Banská Štiavnica, in the village of Štiavnické Bane (Szélakna, Windschacht), on May 15, 1720 and baptized at the Catholic parish church as Maximilianus Rudolphus Höll. ${ }^{2}$

1 Somewhat confusingly, the lands that now comprise Slovakia as a whole are, up to 1918, often referred to as "Upper Hungary" (or "Upper Region": Felvidék), given their overall position in the Kingdom of Hungary. The seven towns are, besides Banská Štiavnica, already mentioned, Pukanec (Bakabánya, Baka-Banya, Pukkhanz); Banská Bystrica (Besztercebánya, Neusolium, Neusohl); Banská Belá (Bélabánya, Bela-Banya, Dilln); Kremnica (Körmöcbánya, Cremnicium, Kremnitz); L'ubietová (Libetbánya, Libetho-Banya, Libethen); and Nová Baňa (Újbánya, Uj-Banya, Königsberg). The overview in the next few paragraphs is based on the following works. Kálmán Demkó, A felsố-magyarországi városok életérốl a XV-XVII. században (Budapest: Magyar Tudományos Akadémia, 1890); Oszkár Paulinyi, "Tulajdon és társadalom a Garam-vidéki bányavárosokban," Történelmi Szemle 5, no. 2 (1962): 173-88; Richard Marsina, ed., Banské mestá na Slovensku (Žiar nad Hronom: Okresný národný výbor, 1990); Gábor Máté, "Az alső-magyarországi bányavárosok etnikai képének történeti és földrajzi vizsgálata," Földrajzi Értesitó 56, nos. 3-4 (2007):181-204. Bratislava became the main administrative center of the residual kingdom as a result of the fall of the medieval capital Buda to the Ottomans in 1541.

2 The change of the orthography of the name has been the subject of some speculation. In official records of the Society of Jesus, for several years after his entering the order Hell appears as "Höll," and he even published his first works under this name in the 1740 s and early 1750 s. His biographer surmised that the motivation was to avoid association with the German word "Hölle" (hell)—certainly bizarre for a Jesuit father. Cf. Pinzger, Hell Miksa, 1:9. While there is 
The tradition of the mining of copper and precious metals in the region goes back to the ancient Celts, and although continuity is hard to establish, the Slavic inhabitants of the area also seem to have cultivated the mines well before their incorporation into the Kingdom of Hungary. From the late twelfth and early thirteenth century, a relatively regular influx of Germans from Thuringia, Tyrol, Saxony, and Northern Bohemia, encouraged by monarchs, not only added to the region's ethnic diversity; the migrants also brought with them new expertise, as well as experience in and triggers to urban autonomy. Royal control via appointed officials (comites et urburarii) was strong, especially in the wealthier and more productive towns. The region's rugged topography also enabled the towns to exist as "life capsules" and to resist the influence of nobles, initially giving protection in times of war or political instability. The first charters of privileges - granting exemption from jurisdiction by the nobility that dominated the county administration, and recognizing the rights to self-government of the local entrepreneurial elite-were conferred on Banská Štiavnica between 1238 and 1255 and on Banská Bystrica in 1255. The other towns achieved the same during the decades of prosperity enjoyed under Hungary's fourteenth-century Angevin rulers. ${ }^{3}$ These urban communities were bound to one another by geographic proximity, similar histories of settlement and incorporation as autonomous entities, similar legal provisions and practices (the code of Banská Štiavnica was adopted more or less everywhere in the area), and shared interests in both business and self-defense. This resulted in the rise of a league among the seven towns, superficially resembling more famous precedents like the Hanseatic League or the league of the Rhineland towns, and more closely others much nearer, like the league of the Spiš towns or those of northeastern Hungary. The league was usually an efficient tool of asserting the interests of the towns at diets, though less a means of resisting military harassment during the conflicts of the late sixteenth and seventeenth centuries, whether by Ottoman forces or the troops of Transylvanian princes, or occasionally the troops of the Habsburg rulers who inherited the Hungarian crown in $15^{26}$.

no conclusive evidence for this, it may be added that in contemporary references in documents of the Imperial Court Chamber, and elsewhere to his father and brother, the forms "Höll" and "Hell" alternate. Cf. Jenő Faller, A magyar bányagépesités úttöröi a XVIII. században: Hell Máté Kornél és Hell József Károly fógépmesterek élete és munkássága (Budapest: Akadémiai Kiadó, 1953), 18-19, 34. Below, Maximilian will be consistently referred to as Hell, as he used it in most of his mature publications, and other family members in the original form as Höll.

3 See Boglárka Weisz, "Mining Town Privileges in Angevin Hungary," Hungarian Historical Review 2 , no. 2 (2013): $288-312$. 
Despite fluctuations, there was a significant amount of economic prosperity, especially in the golden age of Hungarian mining - the only important branch of industry in a predominantly agrarian country - between the fourteenth and sixteenth centuries. The volume of silver production, concentrated around Banská Štiavnica, was the greatest on the European continent (together with the Erzgebirge and Kutná Hora, about twenty-five to thirty percent), and became somewhat eclipsed only after the cultivation of the fields discovered in Potosí in the New World started in 1545. Gold was also found near Kremnica in the early fourteenth century, and it is estimated that in the ensuing period the region supplied eighty percent of the European output and onethird of the total global gold yield. In better times - like under the Angevins, or Matthias Corvinus (1443-90, r.1458-90) - the royal monopoly on the purchase of precious metals and coinage, and the resulting community of interest between the burgher elite of the towns and the court, favored urban growth, as did the attractiveness of the mines (including, in this case, especially those of copper, around Banská Bystrica) for wealthy investors like the Fuggers of Augsburg and their local allies, the aristocratic Thurzó family. The region survived the tripartite division of the kingdom after the 1526 Battle of Mohács in relative economic health, but once the Fifteen Years' War (1591/93-1606) had thrown the economy of the country into disarray, the mining towns suffered, too, and periods of growth alternated with those of decline.

Yet, centuries of relatively steady accumulation bred an appetite, and created the means, for cultural consumption and recognition for the value of good education among the well-to-do burghers that were not stamped out by more or less severe recessions. Studies of last wills and inventories ${ }^{4}$ have revealed the dwellers of especially Banská Štiavnica, Banská Bystrica, and Kremnica to have been eager collectors of art objects and books. Between $155^{\circ}$ and 1750, 2,808 paintings were held in 138 collections, the largest of them boasting as many as 146 , and the owners including not only prominent burghers (among whom the mining entrepreneurs or Waldbürger deserve special mention) and officials but also priests, teachers, and even some artisans. Though the regional centers of book printing lay elsewhere-mainly in Bratislava, Trnava (Nagyszombat, Tyrnavia, Tyrnau), and Košice (Kassa, Cassovia, Kaschau)—many households in the mining towns contained quite impressive private libraries. For Banská Štiavnica in the sixteenth century, twenty-four inventories list a

4 The overview below follows Viliam Čičaj, "Stredoslovenské meštianstvo a výtvarné umenie v období neskorého feudalizmu," in Marsina, Banské mestá, 249-6o; Čičaj, Bányavárosi könyvkultúra a XVII-XVIII. században (Besztercebánya, Körmöcbánya, Selmecbánya) (Szeged: n.p., 1993). 
total of over one thousand titles, with the richest collection (held by the teacher and later chief magistrate Johann Haunold [dates unknown]) alone consisting of 334 items; his Banská Bystrica contemporary, merchant, mint master, diplomat, and humanist scholar Hans Dernschwam (1494-1568/69) possessed a library of 1,062 volumes (but in which over 2,100 separate works were bound together). ${ }^{5}$ This was, of course, exceptional. The average number of books in larger burgher collections grew from 162 in the sixteenth century to 243 in the eighteenth, when libraries of three hundred to five hundred items, noteworthy by general European standards, were not uncommon. Besides the social and intellectual elite of the towns-entrepreneurs, city magistrates, priests, teachers-a wide array of artisans and craftsmen from butchers and shoemakers through locksmiths and saddlers to tanners, bell-founders, and others had small libraries too. By and large, throughout the period Latin and German alternated as the dominant language of the books in the collections, with a small—but slowly increasing - proportion of titles in Czech and Slovak, and a handful of titles in Hungarian. Most of the books, between fifty-five and sixty percent, addressed secular topics, with a preponderance of historical works and ancient classics, but - probably thanks to the practical and technological interests of many possessors in a mining district - an unusually high proportion of them can be associated with the "new science."

Turning to schools, one needs to pay attention to the confessional landscape. As everywhere in Hungary, ${ }^{6}$ the Protestant reform took quick and great strides in the mining towns, where its advance was facilitated by the fact that, as chartered communities, their councils enjoyed the right of patronage and thus the privilege of freely electing their parish priests. Hussite influences and incursions in the area during the fifteenth century and strong business ties with German provinces may also have prepared the ground for the reception of Martin Luther's (1483-1546) ideas. These seem to have been widely circulating and followed in the region in the immediate aftermath of 1517 . Already in 1521, the town council of Banská Štiavnica received orders from King Louis II (150626, r.1516-26) to ensure the safety of the local Dominican friars from harassment

5 Čičaj, Bányavárosi könyvkultúra, 11; for details, see Jenő Berlász, Dernschwam János könyvtára (Budapest: Akadémiai Kiadó, 1964).

6 According to the generally accepted estimate, by 1570 around seventy-five to eighty percent of the population of Hungary had converted to one of the Protestant creeds, leaving Catholics a minority of twenty to twenty-five percent. By the early eighteenth century, the situation was almost the exact reverse. For an overview of the beginnings of the Reformation in Hungary, see Zoltán Csepregi, "Die Anfänge der Reformation im Königreich Ungarn bis 1548," in Die Reformation im Mitteleuropa/Reformacija v srednji Evropi, ed. Vincenc Rajšp et al. (Ljubljana: Založba ZRC, 2011), 127-47. 
by "heretics."7 Although the first parish priest of Lutheran leanings soon left the town, and the Ordo divinorum (Order of divine services) adopted in 1528 does not reflect much change in the liturgy, Pál Várdai (1483-1549), the archbishop of Esztergom (Strigonium, Gran), reiterated the warning about heresy in a letter to the councilors in 1531-not without ground, as from 1529 the local gymnasium used Luther's catechism as the basis of religious instruction, and the new priest, Sigmund (Zsigmond) Staudacher (dates unknown), got married in $1531 .{ }^{8}$ From then on, one royal decree after another was arranged by the archbishop to forbid and sanction similar developments, and generally to counter the tide of the Reformation in Banská Štiavnica, Banská Bystrica, and Kremnica - for the time being, all in vain. ${ }^{9}$ The town councilors coordinated the responses of their communities, which culminated in the adoption of the Confessio montana (Confession of the mines [1559]), the expression of their joint commitment to the cause of Protestantism. ${ }^{10}$ By this time, the parish schools of the towns naturally also came under Lutheran control, and in the 1560 s to the 1580 s their curricula underwent thorough reform established on the priorities of the studia humanitatis. ${ }^{11}$

In this regard, there was actually little difference between Protestant schools and those of the Jesuits, who were first invited to the Kingdom of Hungary by Archbishop Miklós Oláh (1493-1568) - himself a renowned humanist scholar as Nicolaus Olahus-in 1561, and into Transylvania by Prince István Báthori (1533-86, r.1571-86) in 1579. The Jesuit convent and college founded by the former in Trnava (the temporary archiepiscopal see during the Ottoman occupation of Esztergom) was closed as early as 1567 , partly because the first two rectors were arrogant foreigners provoking conflict with the local chapter, and the other members of the crew inexperienced novices. Nor was its re-establishment in Kláštor pod Znievom (Znióváralja) in 1589 lasting. The Jesuit college of Cluj initially fared much better in its rivalry with the Unitarian and Calvinist town schools, but after Báthori's death the Protestant estates prevailed and achieved

7 János Breznyik, A selmecbányai ágost. hitv. evang. egyház és lyceum története. I. A. XVI. századi események (Selmecbánya: Joerges Ágost, 1883), 39.

8 Breznyik, A selmecbányai ágost, 46, 57, 68.

9 For a comprehensive discussion, see Andrea Cobern (née Fröhlich), "Negotiating the Reformation in Habsburg Hungary, c.1520-c.1620: A Case Study of Seven Mining Cities” (PhD diss., University of Cambridge, 2014).

10 Andrea Fröhlich, "The Confessio montana, 1559: Composition and Aftermath/Confessio montana, 1559: Zostavenie a následky," Montánna história 3 (2010): 8-24.

11 István Mészáros, XVI. századi városi iskoláink és a "studia humanitatis" (Budapest: Akadémiai Kiadó, 1981), 84-96. On humanism in the region in the sixteenth century, see further Marcell Sebők, Humanista a határon: A késmárki Sebastian Ambrosius története (1554-160o) (Budapest: L'Harmattan, 2007). 
its closure and, first, the temporary and then the lasting expulsion of the Jesuits from the principality in $1607 .{ }^{12}$

These developments were closely related to the conflicts between the Habsburgs and a part of the Hungarian estates that arose in the context of the turn-of-century Ottoman wars and culminated in the $1604-6$ rebellion led by István Bocskai (1557-1606). However, in the ensuing atmosphere of compromise, the extensive re-conversion of Hungarian magnates and well-to-do nobles began. The resources and the legal security ensured by the patronage of this Catholic elite created favorable conditions for the return of the Jesuitsnot yet in Transylvania, where it occurred after the expulsion of the Ottomans and the fall of the principality at the end of the seventeenth century, but northern Hungary, including the mining towns, which was a natural and early target for their resettlement. Besides the convents, gymnasia and boarding houses were also established, where fees were waived for poor but talented students. The principal locations were Trnava $\left(1615 / 16^{13}\right)$ - where Hungary's first permanent university was also launched in 1635 , as yet with one single faculty, by the learned archbishop, Péter Pázmány (1570-1637)—Bratislava (1622/27), Győr (Jaurinum, Raab, 1627), Sopron (Sopronium, Ödenburg, 1636) Trenčín (1647/49), Prešov (Eperjes, Eperiesinum, Preschau, 1647/73), Banská Bystrica (1648), Banská Štiavnica (1649), Košice (1650 — with another studium generale created in 1660), Rožňava (Rozsnyó, Rosnavia, Rosenau, 1656/9o), Levoča (1673). ${ }^{14}$ During these decades, resources were poured on the Society of Jesus in this new field of operation by the dynasty, by magnates, and-following the example of the latter-by further stakeholders, including town magistrates and other corporate bodies. Records abound in reports about generous cash

12 On the early history of the Society of Jesus in (Upper) Hungary and Transylvania, see András Gyenis, A jezsuita rend hazánkban (Budapest: Szalézi Művek, 1941), 4-9; János Péteri [Antal Petruch], Az elsőj jezsuiták Magyarországon (Rome: n.p., 1963); Emil Krapka and Vojtech Mikula, Dejiny Spoločnosti Ježišovej na Slovensku (Cambridge, ON: Dobrá Kniha, 1990); Antal Molnár, “A jezsuita rend a 16. századi Magyarországon,” Vigilia 64, no. 5 (1999): 348-59; Molnár, Lehetetlen küldetés? Jezsuiták Erdélyben és Felső-Magyarországon a 16-17. században (Budapest: L'Harmattan, 2009). On the Jesuit college of Cluj, see Ágnes Flóra, "Rekatolizáció és provokáció? A kolozsvári jezsuita kollégium alapítása és a városi tanács," in Szentírás, hagyomány, reformáció: Teológia-és egyháztörténeti tanulmányok, ed. Beatrix F. Romhányi and Gábor Kendeffy (Budapest: Gondolat, 2008), 287-96.

13 These dates denote the establishment of the convent and the gymnasium, respectively (where only one date is provided, these coincided).

14 For more on some of these foundations, see Zsófia Kádár, “Jesuitische Kolleggründungen im Westungarischen Raum in der ersten Hälfte des 17. Jahrhunderts: Die Beispiele von Raab/Győr und Ödenburg/Sopron," in Frühneuzeitforschung in der Habsburgermonarchie, Adel und Wiener Hof-Konfessionalisierung-Siebenbürgen, ed. István Fazekas et al. (Vienna: Institut für Ungarische Geschichtsforschung, 2013), 155-70. 
gifts and ambitious construction works, and the inventories list pieces of immovable property, from houses and mansions through mills, arable lands, and vineyards to shops and inns; the convents had the means of employing their own surgeons, apothecaries, masons, carpenters, tailors, shoemakers, butchers, bakers, black- and coppersmiths, and so forth. Municipal councils and mining chambers sometimes provided for the payment of Jesuit schoolmasters. ${ }^{15}$ All of this was far from being politically innocent, nor free of severe conflicts. In Banská Štiavnica, for instance, the Jesuit and Catholic revival was largely thanks to the influence of the superior Raimund Decker (dates unknown), formerly the confessor of Emperor and King Leopold I (1640-1705, r.1657-1705), under whom the town's largest church, hospital, and other facilities were transferred by royal gift to the Jesuits. When the town council refused to comply, three hundred Catholics occupied the church, and the presence of seven hundred imperial mercenaries ensured an atmosphere in which, for the first time in a hundred years, Catholics returned to the municipal assembly. ${ }^{16}$

The variegated sources of patronage enabled the Society of Jesus to strike strong roots in the region, and they also demonstrate that, besides the undoubtedly powerful leverage it received from the imperial and the Catholic hierarchy, this was also thanks to the recognition of the value of the services they provided among the local communities. As a result, the number of Jesuits active in Hungary grew - from 149 in 1650 to three times as many by the beginning and six times as many by the middle of the eighteenth century-and so did the number of their students: the Trnava college alone had 440 students in the year of its foundation, but within just a few years this figure had risen to $700 .{ }^{17}$ As well as the standard curriculum prescribed in the Ratio studiorum, the boarders had the opportunity to receive training in a wide array of other subjects and skills, in response to specific local or social needs. These may have

15 The Acta Jesuitica in the Hungarian National Archives (OL Kam. Lt. Acta Jes.) holds a wealth of relevant material. This brief and impressionistic glance is based on coll. Trench. no. 2151, fasc. 1, fol. 1-8; coll. Leucsov., no. 683, fasc. 7, pp. 185-90. No. 1; coll. Neosol., no. 808 , fasc. 7 , fol. $343-44$. No. 27 , fasc. 7 , fol. $382-87$. Nos. $44-45$.

16 Vendelín Jankovič, Dejiny jezuitov v Banskej Štiavnici: Príspevok k náboženským dejinám mesta od XVI. storočia do konca XVIII. storočia (Bratislava: Vydava Filozofická Fakulta, 1941), 82-87; Ede Richter and Ernő Király, "Selmeczbánya," in Magyarország vármegyéi és városai: Hont vármegye és Selmecbánya sz. kir. város, ed. Samu Borovszky (Budapest: Apolló, 1984), 85-127, here 112; http://www.mek.oszk.hu/o950o/o9536/html/oo11/8.html (accessed April 10, 2019). On the re-Catholicization of towns in general, see István H. Németh, "Unterdrückung oder Reform? Die Rekatholisierung in der ungarischen königlichen Freistädten," in Město v prevratech konfesionalizace v 15. až 18. stoleti, ed. Václav Ledvinka et al. (Prague: Scriptorium, 2014), 435-50. 
included extra-curricular instruction in mathematics, geography, polite letters and good manners, contemporary languages from German, French, and Italian to Hungarian and Slovak-but also fencing, dancing, music, and ball games. ${ }^{18}$ Some locally produced study tools assisted in catering for these, such as the first Hungarian-language textbook, the Grammatica linguae Ungaricae (Grammar of the Hungarian language [1682]) by Pál Pereszlényi (1630-89), ${ }^{19}$ or later the Diarium adolescentis studiosi (Diary of an adolescent student [1697]), a life conduct book for young nobles by historian Gábor Hevenesi (1656-1717).

\section{Turbulent Times and an Immigrant Family around the Mines}

It was into this milieu that the mining engineer Matthäus Cornelius Höll (1650-1743) arrived and settled in Banská Štiavnica in 1694. The end of the seventeenth and the beginning of the eighteenth century was a period of upheaval in the history of Hungary and Central Europe. Generally and in its long-term consequences, it was marked by the "Danubian turn" of the Habsburg dynasty. ${ }^{20}$ After the 1648 peace settlement of Münster and Osnabrück that put an end to the Thirty Years' War and perpetuated religious pluralism and territorial decentralization in the Holy Roman Empire, the Habsburgs turned their eyes and resources to the consolidation and expansion of their possessions east of the River Leitha. At first, their reluctance to concentrate with full determination on the expulsion of the Ottomans from Hungary evoked resentment, even an abortive conspiracy (1671), among a group of impatient Hungarian Catholic magnates. The Viennese response was an attempt to tighten metropolitan hold over the country through government by decree and enhanced military presence, as well as the persecution of Protestants, which in turn provoked the rebellion led by Imre Thököly (1657-1705). As Thököly received support both from Transylvania and the Ottomans, the Habsburg effort to put down the

18 The Jesuit seminarium or convictus nobilium was an institution that adapted especially smoothly to local needs. Cf., for instance, the curricula pursued by students in Bologna as described in Gian Paolo Brizzi, La formazione della classe dirigente nel Sei-Settecento: I seminaria nobilium centro-settentrionale (Bologna: Il Mulino, 1976), 246; for the same in Cluj in Transylvania, see Shore, Jesuits and the Politics of Religious Pluralism, 96-97.

19 Cf. Zsuzsa C. Vladár, "Pereszlényi Pál grammatikája (1682.): Források és párhuzamok," Magyar Nyelv 103, no. 3 (2007): 257-70.

20 The best English-language interpretation of these developments is found in R.J.W. [Robert John Weston] Evans, Austria, Hungary, and the Habsburgs: Central Europe, c.1683-1867 (Oxford: Oxford University Press, 2006), especially 3-98. For a concise overview, see László Kontler, A History of Hungary (Basingstoke: Palgrave Macmillan, 2002), 175-90. 
rebellion became intertwined with the wiping out of the independent Principality of Transylvania in 1691, as well as with the campaign aimed at finally squeezing the Turks out of Hungary. This began after the failure of the last Ottoman siege of Vienna in 1683, and ended with the peace of Karlovci (Karlóca, Carolovicium, Karlowitz) in 1699. However, a genuine settlement could not commence until a decade and a half later. In 1703, another revolt ensued, this time led by the scion of seventeenth-century Transylvanian princes and one of the wealthiest magnates of the country, Ferenc Rákóczi II (1676-1735), who temporarily managed to unite disgruntled nobles, disbanded fortress soldiers, and well-to-do as well as indigent peasants, and to bring substantial parts of the country under his control. Though the Habsburgs were also kept busy on the western front by the War of Spanish Succession (1701-14), the military odds favored them. The legislation of several diets that followed the 1711 Peace of Satu Mare (Szatmár, Szattmarinum, Sathmar) acknowledged their hereditary claim (even in the female line) to Hungary - though they were obliged to issue coronation charters, convene diets regularly, and respect the privileges of the nobility.

While the main theater of the anti-Ottoman war effort was the triangular territory under Turkish control in the central and southern parts of the country, northern Hungary was not spared by these hostilities. The eastern part of the area was the base of Thököly, who among others occupied and ransomed Banská Štiavnica, Banská Bystrica, and Kremnica in 1678 and 1679, and evicted the Jesuits from Banská Štiavnica in 1679 and from Košice and Levoča in 1682. In turn, an extraordinary court set up in Bratislava in 1674 sentenced a group of Protestant preachers to galley slavery, ${ }^{21}$ and another one in Prešov in 1687 had adherents of Thököly tortured and executed. The towns also changed masters several times during the Rákóczi war, resulting in various "calamities" experienced by the Jesuit communities of, for instance, Banská Bystrica and Levoča. ${ }^{22}$ As for Hungary as a whole, the vast and potentially fertile area that the "Holy League" of the papacy, Venice, Poland-Lithuania, Russia, Brandenburg, Saxony, Bavaria, and the Habsburgs conquered for the latter was barren and desolate: Hungary's plains were scorched earth, inhabited by fewer souls than two centuries earlier. In order to redress the situation, large-scale plans for the "refurbishment" of the country, informed bycameralist sciences, populationism,

21 On this, see Marcell Sebők, "Victims of Reformations? 16-17th-Century Refugees and Their Impact on Artistic and Cultural Production," in Expulsion and Diaspora Formation: Religious and Ethnic Identities in Flux from Antiquity to the Seventeenth Century, ed. John Tolan (Turnhout: Brepols, 2015), 135-48.

22 Paul Shore, Narratives of Adversity: Jesuits in the Eastern Peripheries of the Habsburg Realms (1640-1773) (Budapest: Central European University Press, 2012), 173-210. 
and natural law, ${ }^{23}$ were conceived already during the liberation wars, and spontaneous as well as organized resettlement-mostly of several hundred thousand Balkan Orthodox Serbs, and Catholic German "Swabians"-also took place around the turn of the seventeenth and eighteenth centuries.

Matthäus Höll's marriage certificate of November 22, 1707 at the parish registry of Banská Štiavnica, which refers to him as a Gen[erosus] $D[$ omi]nus, a man of respectable social standing, identifies him as natione Bohemus ex Schlackenberg (i.e., "a Bohemian by nation from Schlackenberg"). There is, however, no place called Schlackenberg in Bohemia. A late descendant has put forward "Schlaggenwerth in Bavaria" as Höll's place of origin, also suggesting that Bohemia may have been but a temporary station in the family's migration. ${ }^{24}$ This is contradicted by his identification in the church documents as a Bohemian, which has given rise to speculation about Schlackenwerth, or even Schlaggenwald (in Czech, Ostrov and Horní Slavkov, respectively), both in the Karlovy Vary region in western Bohemia. ${ }^{25}$ The union of Höll, a widower, with Julianna Victoria Staindl (1685-?), ${ }^{26}$ the daughter of an official auditor (Überraiter) ${ }^{27}$ in Štiavnické Bane, was his second marriage. In total, his two marriages produced twenty-two sons and daughters, only some of whom are mentioned in any meaningful historical records. Apart from Maximilian, the youngest of the family, the best known is Joseph Karl (1713-89), who, like his father, became a prodigious engineer and inventor. Ignaz Cornelius (1711-82), who allegedly spoke eighteen languages, also filled various functions around the local mines, while a daughter whose name is not known is said to have been as proficient in mathematics as any student of the Banská Štiavnica mining school established in 1735. There are records of other Hölls working in the

23 László Kontler and Balázs Trencsényi, "Hungary," in European Political Thought 1450-1700: Religion, Law, and Philosophy, ed. Howell A. Lloyd, Glenn Burgess, and Simon Hodson (New Haven: Yale University Press, 2006), 176-207, here 203-4.

24 Pinzger, Hell Miksa, 10.

25 Faller, A magyar bányagépesités úttörői, 18-19; Dušan Janota, "Život Maximiliána Hella/ Das Leben Maximilian Hells," in Maximilián Hell 1720-1792: Zborník prednášok z konferencie o živote a diele Maximiliána Hella, ed. Ján Novák (Bratislava: ÚRAD pre Slovenské banské múzeum v Ban. Štiavnici, 1970), 45-69, here 45. In each case, the German place names — "slag hill," "slag forest"—refer to mining activity.

26 In an autobiography, preserved in his own hand and dated Vienna, June 9, 1773, Hell spells the name of his mother "Juliana Steindlin." Private collection of copies of documents of the late Magda Vargha (1931-2010) at the Miklós Konkoly-Thege Institute of Astronomy in Budapest (hereafter: Vargha priv.).

27 Überreiter is interpreted by Norbert Weyss, "Maximilian Hell und sein Fernsehen vor 200 Jahren, Part II," Maria Enzersdorfer Kulturnachrichten (December 1986): 4 as kaiserliche [r] Rechnungskontrollor; by Pinzger, Hell Miksa, 1:10, simply as ellenör (controller). 
mines of the region and elsewhere, whose relationship with Matthäus Cornelius cannot be established with full certainty: Georg, mentioned in Baia Mare (Nagybánya, Rivulus Dominarum, Neustadt) in Transylvania in 1737, and Joachim Michael (1724-61), the operator of the water pumps designed by Joseph Karl in Štiavnické Bane in $1751^{28}$

Höll senior's relocation to Banská Štiavnica, while coinciding with the major population movements mentioned above, is more helpful to explain in the context of the long-standing tradition of the migration of mining experts into the region in answer to the specific needs of the industry. Many of the new developments in it depended on special expertise. In addition, given the lack of other major industries and persons with relevant skills, mining and metallurgical experts were often also charged with various tasks in general mechanical engineering, construction works, water regulation, and even forestry and wood processing. While mining was a strategic branch for Vienna, ${ }^{29}$ it also required permanent attention. The ups and downs in the seventeenth-century fortunes of the mines in the region were not only due to the endemic wars in the territory of Hungary and the competition of the New World. The resources were still plentiful, but in order to reach the ores, deeper and deeper shafts were needed. Explosives were used to develop these in Banská Štiavnica, a pioneer in this respect, as early as $1627 .^{30}$ The removal of water also became an increasingly formidable technological challenge, no longer manageable by

28 Information on Hell's family has been culled mainly from Pinzger, Hell Miksa, 1:9-13; Faller, A magyar bányagépesités úttörői, 18-20; Anton Pinsker, "Der Astronom Pater Max Hell S.J.," Freinberger Stimmen [Linz] 41 (1971): 99-111. Cf. Janota, "Život Maximiliána Hella," 45-47; Ferencová, Maximilián Hell, 9-13. Some authors speak of Maximilian Hell as one of twenty-three, not twenty-two, sons and daughters of Matthäus Höll. As the Mining Archive in Banská Štiavnica preserves several accounts signed by Joachim Michael in the same file that also holds plans of machinery and further accounts deriving from Matthäus Cornelius and Joseph Karl, their relationship is quite likely. Štátny ústredný banský archív v Banskej Štiavnici (šÚ BA Bš), H KG 2617. The same archives also contain as many as thirty-two contemporary maps of mines and shafts attributed in the catalog to "František Kornel Hell," who, however, is not mentioned in any other source known to us.

29 In the 1770s, thirty percent of the income of the treasury in Hungary (and fifty percent in Transylvania) derived from the mines, while between seventy and eighty-five percent of the value of mining in the Habsburg monarchy came from these two provinces. Sándor Tar and László Zsámbék, eds., Selmectól Miskolcig, 1735-1985: A magyarországi müszaki felsőoktatás megindulásának 25o. évfordulójára (Miskolc: Nehézipari Műszaki Egyetem, 1985), 7-8.

30 Antal Péch, Alsó-Magyarország bányamívelésének története (Budapest: Magyar Tudományos Akadémia, 1884-87), 2:225-31. The innovation was introduced by the Tyrolean immigrant expert Caspar Weindl, invited to Banská Štiavnica by Count Hieronymus Montecuccoli as chief shareholder of the main mining company there. 
human or animal power: in 1687, out of the 2,173 workers of the mines in Banská Štiavnica, 720, one-third, were employed in lifting the water, while only 474 , less than one-quarter, were employed in the actual production. ${ }^{31}$ This could only result in huge deficits, so that many of the smaller mining companies had gone bankrupt by the 1690 , and at times even the overall closing down of the mines was contemplated by the wielder of sovereign control—whoever that might be at the given moment.

Whether Matthäus Höll's move to Banská Štiavnica was directly linked with this critical situation or not, ${ }^{32}$ thanks to his qualifications-he is said to have been well versed in mathematics, mechanics, and chemistry — he began to play important roles in meeting the challenges soon after his arrival. As Oberkunstmeister (roughly, chief engineer), he prepared plans for replacing horse and human power with water-wheel driven machinery to operate the pumps, and to exploit the topography of the region for developing artificial lakes with a view to ensuring and regulating adequate water supply. He also constructed mechanical devices for the easier delivery of ore from the shafts. These plans were approved in 1699 by the Imperial Court Chamber, the ultimate supervisory authority of the mines, and their implementation began in the following year.

Soon enough, however, this was interrupted by the occupation of the town by the troops of Rákóczi, whose urgent need for resources led to a predatory exploitation of the mines during the years after 1703. Realizing that this was unsustainable, Rákóczi decided to close down the mines altogether and commissioned his close associate, General Miklós Bercsényi (1665-1725), to demolish them. It was Höll who prevented this: in an apparently dramatic scene, he convinced Bercsényi that investing in the further improvement of the machinery would salvage the national assets that the mines represented. ${ }^{33}$ While this prediction proved too optimistic in the short run, Höll managed to perform essentially the same feat a few years later. The consequences of the 1708 Battle

31 The data derive from the Epistolae itinerariae (1700) of the Dutch scholar Jakob Toll (Jacobus Tollius [1633-96]), who visited the region in 1687 . See Johann Kachelmann, Das Alter und die Schicksal des ungarischen zunächst Schemnitzer Bergbaues (Bratislava: n.p., 1870), 182.

32 It is not unlikely that before his final relocation, Höll had already visited the town as a young man. Sources like the Bericht von Wasser-Werken by the renowned Viennese cameralist Johann Joachim von Becher (1635-82), who also made significant contributions to mineralogy, mention that during the pillage of the town by Thököly's captain, "Pater" István Józsa, in 1679, the first specimen of a type of water pump whose invention is attributed to Höll was destroyed. Cf. Faller, A magyar bányagépesités úttörői, 33.

33 Antal Péch, A tudományok haladásának befolyása a selmeczvidéki bányamüvelésre (Budapest: Magyar Tudományos Akadémia, 1881), 15. 
of Trenčín returned Banská Štiavnica to Habsburg hands, and in 1710 the Imperial Court Chamber ordered the closure of the mines once again. But Höll obtained an audience with Joseph I (1678-1711, r.1705-11), and pleaded with the emperor so successfully that he secured funds for the development of another lake and the construction of a new water pump. ${ }^{34}$

Within a generation—quite literally, as Höll senior's position was later filled by his son Joseph Karl ${ }^{35}$ — Höll's perseverance was crowned with significant success. While elsewhere in the region engineers had already experimented with primitive and high wood consumption steam engines (called "fire engines"), the Hölls insisted on further improving the technology based on water. Several new lakes were constructed for power supply, and Joseph Karl replaced traditional water mills with real hydraulic machines. Inundations were at least temporarily contained, and as a result, from the late 1730s the mines of Banská Štiavnica witnessed a new golden age that lasted until the end of the eighteenth century. In 1740 alone, 2,429 marks of gold and 92,267 marks of silver were produced, and the income from the mines over the following two decades was a staggering forty-two million florins; the population of the town around $175^{\circ}$ is estimated at about twenty thousand (six thousand of them working in the mining industry), making it the second largest in northern Hungary, surpassed in the area only by Bratislava. ${ }^{36}$ Prosperity and success also stimulated an innovative and "curious" spirit: after long-standing traditions of training qualified staff in the region by guild-like methods, it is no coincidence that in 1735 Banská Štiavnica became the seat of a proper mining school (Montanistiche Schule), ${ }^{37}$ established by order of the Imperial Court Chamber.

34 Kachelmann, Das Alter und die Schicksal, 191-92.

35 Many of the cunning devices in place in Banská Štiavnica around 1770 are attributed to Joseph Karl, not his father, in Nikolaus Poda, Kurzgefaßte Beschreibung der, bey dem Bergbau zu Schemnitz in Nieder-Hungarn, errichteten Maschinen (Prague: Walther, 1771), 51, 54, $57,61,66,70,74$.

36 Figures are taken from Jozef Vlachovič, “Banská Štiavnica—prostredie, v ktorom vyrastal Maximilián Hell/Banská Štiavnica—das Milieu, in dem Maximilián Hell herangewachsen war," in Novák, Maximilián Hell, 31-42.

37 The sketch on the development of the school below is based chiefly on Tar and Zsámbék, Selmectól Miskolcig, especially 13-17, 31-36, 45-52, 65-66, 90-100. The same volume also includes several sources (in Hungarian translation). On the school in the overall context of academic life in eighteenth-century northern Hungary, see Ján Tibenský, "Pokusy o organizovanie vedeckého života v Habsburskej Ríši a na Slovensku v 18. storoči/Versuche zur Organisierung des wissenschaftlichen Lebens im Habsburgerreich und in der Slowakei in 18. Jahrhundert," in Novák, Maximilián Hell, 3-25. See also Peter Konečný, "Die montanistische Ausbildung in der Habsburgermonarchie, 1763-1848," in Staat, Bergbau und Bergakademie: Montanexperten im 18. und frühen 19. Jahrhundert, ed. Hartmut Schleiff and Peter Konečný (Stuttgart: Felix Steiner Verlag, 2013), 95-124; Peter Konečný, 250. 
Following the model of the similar school in Jáchymov (Sankt Joachimsthal) in Bohemia, founded in 1716, it offered a two-year curriculum for eight students, focusing on applied mathematics and physics (but, given the intricate legal affairs involved in the mining industry, also law) and supported by a specialized library of up-to-date literature on engineering and natural knowledge. Instruction was free of charge and open to Catholics and Protestants alike, but admission was conditional on passing an exam in arithmetic; students from a poor background received scholarships. This institution was upgraded to a "practical training school" (Praktische Lehrschule) in 1763-with a course of studies in which, despite the name, the emphasis on theoretical background was to be enhanced - until in the year 1770 it was renamed again, to become a mining academy (Bergbauakademie) with a curriculum defined in the Systema Academiae Montanisticae (System [of studies] of the Mining Academy) extended to three years.

Some assessments of the impact of the school, especially in the early years when most of the training was done by the mining officers who were all too busy in their main job, are skeptical. ${ }^{38}$ However, the institution already boasted some outstanding faculty members in this period, such as Sámuel Mikoviny $(1698 / 1700-50)$, the renowned mathematician, engineer, and cartographer. ${ }^{39}$ Mikoviny is generally regarded as the founder and main theoretical fountainhead of scientific cartography in Hungary, whose formidable legacy in this field - thirty-nine county and district maps ${ }^{40}$-is perhaps thanks to the unique combination of training in engraving as well as mathematics, astronomy, and land surveying at the universities of Nuremberg, Altdorf, and Jena, and subsequently privately in Vienna. It has been conjectured that Mikoviny, besides serving in times of war as an army officer for purposes of military engineering, and from 1735 as supervisor of the engineering sector of the mines as

výročie Banskej a lesnickej akadémie v Banskej Štiavnici: Jej význam pre vývoj montánneho školstva v Rakúsko-Uhorsku, 1762-1919/250. Jubiläum der Berg- und Forstakademie in Schemnitz; Ihre Bedeutung für die Entfaltung des höheren Montanschulwesens in Österreich-Ungarn, 1762-1919 (Košice: Banská agentúra, 2012), 12-53.

38 János Mihalovits, A selmeci bányászati akadémia alapitása és fejlődése 1846-ig (Budapest: József Nádor Műszaki és Gazdaságtudományi Egyetem, 1938), 3.

39 On Mikoviny, see Enikő Török, Mikoviny Sámuel (Budapest: Magyar Országos Levéltár, 2011).

40 These maps accompanied the five volumes of the Notitia Hungariae novae historicogeographica (1735-49) by Mikoviny's master, polymath Mátej Bel or Mátyás Bél (16841749). On Bél, Mikoviny, and the beginnings of Landeskunde (honismeret-roughly, local history, literally "science of the fatherland") in Hungary, see Zsolt Török, Bél Mátyás, Mikoviny Sámuel és a honismereti iskola (Budapest: Országos Pedagógiai Könyvtár és Múzeum, 2003). 
well as a professor at the Montanische Schule in Banská Štiavnica, also constructed an observatory there as a base for his lectures in astronomy, and inspired the young Maximilian Hell to study the subject. Unfortunately, there are no sources corroborating this attractive assumption. ${ }^{41}$ It is certain, however, that Mikoviny taught Hell's brother Joseph Karl, as well as other distinguished figures of the local mining scene, such as Christoph Traugott Delius (1728-79), who would also become a professor at the same school. ${ }^{42}$ Another important polymath associated with the school in its early years was the botanist and medical doctor Nikolaus Joseph von Jacquin, appointed as professor of Bergwissenschaften (mineralogy and chemistry) in Banská Štiavnica in 1762 . Von Jacquin, of French background but a native of Leiden, was invited to Vienna by the Dutch court physician and reformer Gérard van Swieten (1700-72), with whom he finished his studies. He then embarked, on commission from Emperor Francis I (1708-65, r.1745-65), on a long voyage to the West Indies (175559), returning with ethnographic objects as well as plant and animal specimens for the Schönbrunn gardens. After a period at the Praktische Lehrschule, von Jacquin became the director of the new Viennese Botanical Gardens, and at the end of his long life he served as rector of the university. ${ }^{43}$

41 Pärr, Maximilian Hell, 76, 124. The account of an observatory in Banská Štiavnica seems to be based on a misunderstanding. The source, Programma de speculis uranicis celebrioribus [Lecture concerning famous astronomical observatories], was presented by Johann Heinrich Müller (1671-1731) in Altdorf (where Mikoviny later studied) on August 15, 1713 (not 1723, as alleged by Pärr); it was later included in a volume of collected works from 1731. In this Programma, Müller explicitly mentions that he has recently built an observatory in Altdorf. There is no mention whatsoever of Banská Štiavnica in this source. See Joh. Henrici Muelleri, In Universitate Norimbergensium Altorfina Philosophiae Nat. \& Mathem. Professoris Publici, Collegium Experimentale: In quo Ars experimentandi, praemissa brevi eius delineatione, Potioribus aevi recentioris Inventis ac Speciminibus, de Aere, Aqua, Igne ac Terrestribus, explanatur ac illustratur, \& ad genuinum Scopum Usumque accommodatur (Nuremberg: Endterus, 1731), 254-67, especially 266-67.

42 Delius's work Anleitung zu der Bergbaukunst nach der Theorie und Ausübung (1773), besides Poda's Kurzgefaßte Beschreibung, mentioned above, is also the chief primary source from which the devices constructed by Matthäus Cornelius and Joseph Karl Höll are known.

43 On the significant contributions of von Jacquin as a botanist, see Maria Petz-Grabenbauer, "Zu Leben und Werk von Nikolaus Joseph Freiherr von Jacquin," Wiener Geschichtsblätter 50, no. 3 (1995): 121-50; Klemun and Hühnel, Nikolaus Joseph Jacquin. A friend of von Linné whose system he championed in Austria and applied to the local flora in a series of monumental publications, von Jacquin's chief works also included the Selectarum stirpium americanarum historia (1763), which has been made available in a splendid edition with a substantial introduction. See Santiago Madriñán, Nikolaus Joseph Jacquin's American Plants: Botanical Expedition to the Caribbean (1754-1759) and the Publication of the Selectarum stirpium americanarum historia (Leiden: Brill, 2013). 
The school and the mines in the area had become established as a popular destination for the study trips of aspiring mining engineers from various parts of Europe. ${ }^{44}$ Another individual who played an important part in developing the region's appeal was Ignaz von Born (1742-91), a nobleman of Transylvanian Saxon origin and one of the shining lights of the Austrian Enlightenment. An eminent mineralogist and a member of several European scientific academies, in the 1770 s he himself organized in Prague the Privatgesellschaft, a "private society" regarded as the predecessor of the Czech Academy of Sciences, and arranged in Vienna the imperial natural history cabinet that was the base of the later Museum of Natural History. As grand master of the Viennese lodge Zur wahren Eintracht (For genuine harmony) in the 1780s, von Born was a leading freemason and the author of radical satirical pamphlets on subjects such as monasticism (as we shall see, with Maximilian Hell as an especial target) and bureaucratization, while also an imperial administrator playing important roles in the department of mines and the mint. In this latter capacity, he had a short spell in Banská Štiavnica in 1769-70 as Oberstkammergraf (supervisor of the mines for the imperial chamber) and began collaboration with the professors of the mining academy there. In the 1780 s, he returned to nearby Skleno/ Sklené Teplice (Szklenó/Turócnémeti, Glashütte/Glaserhau/Glaserhütte) to continue experiments in the amalgamation of metals begun in the laboratory of the Viennese court pharmacy. The most glorious moment in the region's eighteenth-century scientific history is probably the gathering of mining and metallurgical experts in Skleno in 1786, interested in von Born's method. On von Born's initiative, this meeting resulted in the founding of the famous Society for the Art of Mining (Societät der Bergbaukunde), a truly international association that soon established chapters in fourteen countries, attracting over 150 members in Europe and America for research in mining and associated industries. ${ }^{45}$

44 See Peter Konečný, “Cestopisy európskych odborníkov ako forma komunikácie poznania o baníctve a hutníctve v Uhorsku, 1651-1759/Reiseberichte europäischer Fachleute als Kommunikationsform des Wissens über das Berg- und Hüttenwesen im Königreich Ungarn, 1651-1759," Montánna história 7 (2014): 200-39.

45 On von Born generally, see Helmut Reinalter, ed., Die Aufklärung in Österreich: Ignaz von Born und seine Zeit (Frankfurt am Main: Peter Lang, 1991). On von Born's work in amalgamation, see Lothar Suhling, "Von der Alten zur Neuen Welt und zurück: Der Vor- und Frühgeschichte der Europäischen Amalgamation nach Ignaz von Born im Überblick," in Technik, Arbeit und Umwelt in der Geschichte. Günter Bayerl zum 6o. Geburtstag, ed. Günter Bayerl, Torsten Meyer, and Marcus Popplow (Münster: Waxmann Verlag, 2006), 77-94. On von Born and the Society, see Günter B. Fettweis and Günther Hamann, eds., Über Ignaz von Born und die Societät der Bergbaukunde: Vorträge einer Gedenkveranstaltung zur 200; Wiederkehr des Gründungstages im September 1786 der ältesten internationalen 
Maximilian Hell was born and raised in a closely knit region marked by abundant natural resources and a potential for economic prosperity, ethnic, linguistic, religious, and cultural diversity, and strong civic traditions, including those of municipal self-government as well as urban sociability and sensitivity to the value of intellectual and educational goods. During the "long century" of his lifetime, the region saw periods of calamity and instability as well as recovery, in which local tradition and initiative intersected with the increasingly systematic endeavor of the Habsburg state apparatus to support technological innovation, with a view to the rationalization and maximization of resource exploitation. Maximilian's family legacy and environment comprised geographic and social mobility and adaptability, high levels of personal integrity and authority, as well as intellectual adroitness and ingenuity. Altogether, this was a heavy baggage of assets for the ambitious youngest son of the seventy-year old Oberkunstmeister of the Banská Štiavnica mines.

\section{Apprenticeship}

Maximilian Hell grew up in a respectable, mansion-like family home. It was still standing on the steep slope opposite the "maiden fortress" of Banská Štiavnica, a fortified tower erected in the sixteenth century to watch out for movements of Turkish raiders, at the time when his early twentieth-century biographer described the early circumstances of his life. ${ }^{46}$ Little else is known about these circumstances, apart from the fact that after completing elementary school in Banská Štiavnica, his path diverted from what seems to have been regular in the family. Unlike Joseph Karl, who received some training in engineering, mechanics, hydraulics, and physics from his father and entered service in the machinery workshop of the mines before he was twenty (though later, in 1737, he did attend Mikoviny's courses), ${ }^{47}$ the young Maximilian was sent to study in the Jesuit gymnasium in nearby Banská Bystrica.

While there is no direct evidence about the background and circumstances that led to this decision, the sources allow some informed conjectures. In a family such as his, Hell could hardly have avoided exposure to mathematics

wissenschaftlichen Gesellschaft (Vienna: Verlag der Österreichischen Akademie der Wissenschaften, 1989). See also Tibenský, "Pokusy o organizovanie vedeckého života," 22. The operational rules of the society (including a list of the directors of the national chapters) are reproduced from its short-lived journal Bergbaukunde in Tar and Zsámbék, Selmectől Miskolcig, ${ }^{100-3}$.

46 Pinzger, Hell Miksa, 1:9.

47 Faller, A magyar bányagépesités úttöröi, 39. 
and related fields, which in turn may have revealed his special talents to his elders. The same discovery could have been made by a teacher, or indeed the local Jesuits themselves, who not only maintained a convent in Banská Štiavnica but also performed ordinary parish duties due to a lack of secular priests, and were thus a permanent presence in the everyday life of the urban community. In this sense, the Society of Jesus was no different from the mining chamber, the chief employer in the town. The relationship between the two entities went beyond such parallels: several documents show the mining chamber to have shown concern with the proper care of the souls of their workers by the Jesuits to whom this was entrusted, and a willingness to support the efforts of the Society with financial donations. ${ }^{48}$ The Hölls as both prominent figures in the mining sector and staunch Catholics may well have been brokers in this relationship. Interesting light is shed on this in a letter from the superior of the Banská Štiavnica residence, Father Anton Grueber (1701-46), to Queen Maria Theresa, probably in 1744, the year after Höll senior had died and when Grueber was appointed. Grueber began by reporting that the miners of the area "have humbly solicited us already for the second time to secure a place in Windschacht for the better worship of God and the special comfort of their souls, and to provide two fathers, the one proficient in the German and the other in the Slavic [i.e., Slovak] language" for this end. He went on to make the following recommendation:

Now, as in consequence of the death of the former Kunstmeister Cornel Hell a shabby house, consisting of two very small and one somewhat bigger room, belonging to the Chamber here, has become vacant, it would suit us very well because of its vicinity (it is just a few footsteps from our filial church of St. Joseph). ${ }^{49}$

48 MOL, E 152 Acta Jesuitica, Irreg. Coll. Schemn. 13. t. 3-7.

49 šÚ вA вŠ, HKG 2617, 35. On Grueber, who was himself also an ethnic German native of Banská Štiavnica, see the online compendium of Jesuits in Hungary based on the legacy of the eminent Hungarian Jesuit, László Szilas (1927-2012), Jezsuita névtár; http://jezsuita. hu/nevtar/grueber-antal/ (accessed April 12, 2019). Besides Szilas's work, we have also used other collections of a prosopographical nature about Jesuits, according to the different angles from which they look at Jesuits for different purposes. These include Carlos Sommervogel's (1834-1902) monumental Bibliothèque de la Compagnie de Jésus [...] Bibliographie, 12 vols.(Brussels: Oscar Schepens, 1890-1932); László Lukács, Catalogi personarum et officiorum provinciae Austriae S.I., 9 vols. (Rome: Institutum Historicum S.I., 1994); and http://www.jesuitscience.net/ (accessed April 12, 2019), created as part of a PhD project at the University of Wuppertal by Dagmar Mrozik. 
A lengthy justification followed, with reference to the growing number of the flock, and the consequent needs in terms of baptismal, funerary, and other services.

From the point of view of a family such as the Hölls, a member's association with (and possibly recruitment in) the Society of Jesus may have been a source of spiritual consolation and pride-besides being an opportunity to equip a bright son with the best education available, and the more mundane advantage of having one less mouth to feed. As Joseph Karl was by this time already establishing himself in the footsteps of his father, and the other brothers also seem to have filled positions around the mines, the career prospects there may have become restricted. While receiving a Jesuit education did not necessarily mean a life-long association with the Society, Hell did make the crucial step of applying for membership in the order and was admitted for his two-year novitiate in Trenčín on October 17, $1738 .^{50}$

In terms of the organization of the Society of Jesus, the territory where Hell grew up, pursued his studies, and began his career in the order belonged to the Society's huge Austrian Province (Provincia Austriae or Austriaca). A map drawn by Johann Baptist Mayr (1681-1757), prelate of the Abbey of Rebsdorf in Bavaria and published by the prolific Augsburg map publisher Matthäus Seutter (1678-1757) around 1727-30 (reproduced in Appendix 1 of this book), shows the extent of the province, with all its main schools and houses, as Hell knew it from his youth until the suppression of the order in 1773. The province extended from Passau and Salzburg through the Austrian lands south of the Danube and the whole of the Kingdom of Hungary (including modern Slovakia and Croatia), to Transylvania, and even to the missions in the north Balkans. Originally, the Austrian province had been part of an even vaster province of South Germany (Provincia Germaniae Superioris), from which it was separated in 1583 . While a Bohemian province had been carved out of the Austrian one in 1622 , occasional initiatives to create an independent Hungarian province were thwarted. ${ }^{51}$ Nevertheless, Hungarians and Slavs would be appointed as superiors of the Austrian province besides Germans. Furthermore, the rectors of the larger houses, themselves of very diverse origins, often played roles beyond their normal functions: as the mandatory annual visitation of all

5o Pinzger, Hell Miksa, 1:13. It may be of interest for Hell's itinerary and mobility in the region that while he graduated from Banská Bystrica, for unknown reasons the application took place-according to the records of the Jesuit residence in Trnava, which Pinzger claims to have used—in the town of Žilina (Zsolna, Solna, Sillein).

$5^{1} \quad$ See László Lukács, A független magyar jezsuita rendtartomány kérdése és az osztrák abszolutizmus (1649-1773) (Szeged: Szegedi I. sz. Magyar Irodalomtörténeti Tanszék, 1989). 
the houses of the province could not be carried out by the superior, the task was delegated to these rectors.

As for the Jesuit rank-and-file, its growth in number during the eighteenth century reflected the continuing vigor of the Society - and the support of the Catholic dynasty and government in Vienna-after the expulsion of the Ottomans from Hungary. The number of brethren in the whole of the Austrian province rose from around a thousand in 1651 and 1,300 in 1716 to a record high of 1,904 in 1767, out of which 1,038 were active in the fifty smaller or bigger convents in the territory of Hungary. ${ }^{52}$ Their background was as diverse as the ethnic and linguistic composition of the Habsburg monarchy. On the basis of forms filled in at the entrance of each novice (usually still in their teens), it has been established that of the total number of "Austrian" Jesuits who were around in 1773, forty-four percent came from Austria, and forty-one percent from the Kingdom of Hungary. ${ }^{53}$ The remaining fifteen percent derived largely from neighboring territories under Habsburg rule or the Holy Roman Empire, such as Bavaria, Bohemia, Moravia, Silesia, or Tyrol. The form also contains information about the novices' linguistic skills. Knowledge of Latin had been instilled in all these Jesuits from a young age, as it not only formed the core of the curriculum in the Jesuit schools but its use was also compulsory in conversation. ${ }^{54}$ As for vernacular languages, nearly sixty-five percent of the "Austrian" Jesuits of Hell's generation were recorded to have known German well (bene), whereas only thirty percent were in command of Hungarian. Nearly as many mastered a Slavic language (seventeen percent Slovak, eleven percent the

52 These figures are taken from András Gyenis, Régijezsuita rendházak: Központi kormányzat (Vác: n.p., 1941), 5-6. It is noteworthy that the average number of members in a province in the mid-seventeenth century was four hundred to eight hundred (and the Bohemian province was set up with fewer than three hundred). Practical considerations thus may well have warranted the division of the Austrian province and the creation of a Hungarian one. It has been suggested that the reasons why this did not happen included rivalry and mutual suspicion between Jesuits of Austrian and Hungarian background, and the courtly influence of the former, who also alleged their Hungarian colleagues to be both "barbarous" and much too sympathetic to the nationalist cause. See Lukács, A független magyar jezsuita rendtartomány kérdése, passim.

53 László Szilas, "Austria I. Antigua," in Diccionario histórico de la Compañía de Jesús: Biográfico-temático, ed. Charles Edward O'Neill and Joaquín María Domínguez (Rome: Institutum historicum S.I., 2001), 1:277-92, here 1:286-87. See also Félix Litva, entry entitled “Eslovaquia," in O’Neill and Domínguez, Diccionario histórico de la Compañía de Jesús, 2:1262-65.

54 See Joseph Bruckner, La Compagnie de Jésus: Esquisse de son institut et son histoire (Paris: Gabriel Beauchesne, 1919), 444-49; Peter Burke, Languages and Communities in Early Modern Europe (Cambridge: Cambridge University Press, 2004), 54. 
language that in more recent times is known as Croatian), 55 followed by seven percent Italian, one percent Romanian, and one percent French speakers. Biand trilingualism, then, must have flourished among the novices of the Austrian province. The eighteen-year-old Maximilian Hell was no exception. According to the list of novices at Trenčín, he knew Latinam, German[icam], Slav [icam] bene (Latin, German, and Slavic [Slovak] well). ${ }^{56}$ One notices the absence of Hungarian in this entry: the ethnic Hungarian component in the population of Upper Hungary was meager. But as we shall see, even those who, like Hell, had no Hungarian, could still refer to themselves as a Hungarus and characterize Hungary as their patria.

Hell spent most of his adolescence and early adulthood in the milieu of the Jesuit colleges of northern Hungary, in towns that were of great importance to the intellectual and cultural development of the kingdom as a whole. His formation there was interrupted by years of higher training at the University of Vienna. It is helpful to consider what can be garnered, mainly from sheer data and indirect evidence, about Hell's experiences in the former places, and then return to the Viennese years. Banská Bystrica, already mentioned several times as an important center in the mining district, within a long day's walk from Hell's hometown, was the site of a medium-sized Jesuit college with around thirty members ${ }^{57}$ during the time of Hell's secondary studies there. Thus, in terms of weight and significance, it belonged to the second tier of Jesuit establishments in the region, surpassed only by Trnava with its residence, college, and university and around a hundred members (itself second only to Vienna and Graz in the whole of the Habsburg lands), and Trenčin, the seat of the only other novitiate besides Vienna in the entire Austrian province of the Society, with over seventy members (including the novices, overwhelmingly recruited from the Kingdom of Hungary). By contrast, the college of Levoča, where Hell was sent to take up his first teaching position upon his graduation as a magister from the University of Vienna in 1745, was a relatively small institution, with

55 Szilas, "Austria," 287. It is difficult to find a neutral designation for the Slavic languages of the eighteenth century. For a balanced and well-informed discussion in English, see Tomasz Kamusella, The Politics of Language and Nationalism in Modern Central Europe (Basingstoke: Palgrave Macmillan, 2009).

$56 \quad$ Nomina noviciorum secundum Ordinem, quo ingressi sunt in hanc domum probationis Trenchinij Provinciae Austriae Societatis Jesu, under the heading Quas linguas calleat (quoted after Pinzger, Hell Miksa, 1:13).

57 Members of Jesuit colleges included fully ordained priests (sacerdotes), magisters (graduates of lower university studies), secular assistants (coadiutores temporales), and in the case of training houses, novices (novitii). 
fewer than twenty members. ${ }^{58}$ Hell spent two years in Levoča, teaching grammar and syntax in his first year and rhetoric and poetry in the second, when he was also assigned with keeping the historia domus (history of the house) and acted as an assistant to the local clergy, Patris regentis socius. He was also the chair of the pupils' congregation of the Virgin Mary, a function in which he could exercise his own rhetorical skills. ${ }^{59}$

Levoča was a unique place from a different point of view than the other localities where Hell had spent time so far. In the far-away northeast of Upper Hungary, it belonged to the group of Spiš towns, which had enjoyed a set of privileges defined on a regional basis since the thirteenth century, and the political picture was further complicated by the fact that the right to tax these lands had been mortgaged to Poland by the king of Hungary in 1412, an arrangement that continued until the first partition of Poland in $177^{2}$. Better known in the period by its German name Zips, the area was much of a "language island" (Sprachinsel) where Protestantism had gained an early foothold. Its cultural and political association with Vienna was thus comparatively loose not only because of physical remoteness, and it is no coincidence that early in the eighteenth century the Rákóczi revolt drew a great deal of support in Spiš. The presence in Levoča of a Jesuit gymnasium and other Catholic institutions was part of Viennese efforts to stabilize this area as a loyal hinterland of the empire. ${ }^{60}$ Still, even though in Levoča as well as in all the other towns where Hell spent his youthful years, a Lutheran majority was preserved among the inhabitants, confessional relations in the period seem to have been relatively calm. ${ }^{61}$ Protocols of the town magistrates rarely refer to the Jesuits-and then in neutral contexts - and while the residence or the college was often party to litigation over property, debt, or other matters, these were not different in

$5^{8} \quad$ The figures given are approximate because there was naturally some fluctuation over the years. They are based on Lukács, Catalogi personarum, 8 (1734-47): 140, 333, 757. This invaluable collection also provides full membership lists of all Jesuit colleges, residences, and missions in the Austrian province. On the Jesuit period of the Catholic gymnasium in Levoča, see László Halász, A lőcsei királyi katholikus fógymnasium története (Lőcse: Reiss József, 1896), 14-39.

59 Lukács, Catalogi personarum, 8:821.

6o On the cultural history of the area, see Wynfrid Kriegleder, Andrea Seidler, and Jozef Tancer, eds., Deutsche Sprache und Kultur in der Zips, Presse und Geschichte: Neue Beiträge 24 (Bremen: Edition lumière, 2007).

61 This was despite the fact that the latest settlement of religious affairs in the Kingdom of Hungary, the Carolina resolutio issued by Charles VI/III in 1731, still restricted rights of worship by non-Catholics, allowed them very limited self-government, kept mixed marriages under the control of the Catholic Church, and punished conversion to any version of Protestantism. 
character from affairs of similar kinds between parties belonging to the same denomination. ${ }^{62}$

Vienna, where Hell interrupted his Upper Hungarian trajectory for three years of studies in philosophy (logics, physics, and metaphysics) and two in mathematics at the university during the early 1740 s, and where he returned to complete the curriculum in theology at the end of the decade, had an altogether different ambience. Academic life in Vienna had by then been steeped in Jesuit erudition for nearly two centuries. ${ }^{63}$ At first, Vienna seemed a fertile soil for the Reformation, and the early measures to counter its spread included some reforms at the University of Vienna in the 1530s, as well as the invitation of the Society of Jesus to the city by Ferdinand I, king of Hungary and Bohemia, who ruled the Habsburg hereditary provinces on behalf of Emperor Charles $\mathrm{V}$ $\left(1500-58\right.$, r.1519-56) in $155^{-}-51$. A Jesuit college was opened in Vienna at the same time, under the leadership of Claude Le Jay (Claudius Jajus [1504-52]), Ignatius of Loyola's close associate, who immediately conceived a plan of bringing all faculties of the university except law and medicine under the college as a fully public institution, getting rid of "heretical" professors.

As soon found out by Le Jay and the renowned Dutch Jesuit theologian Peter Canisius (Petrus Canisius [1521-97]), who was also brought to Vienna in 1553 to lead the work of the Reformkommission of the university, this was not practicable because of a shortage of competent "non-heretic" professors. The Nova reformatio of 1554, a new constitution of the university that remained in effect until the Theresan and Josephian reforms beginning in the 1750s, reduced the corporative character of the university and increased the possibilities for interference by the territorial sovereign (Landesherr), who, however, also

62 This is revealed by a survey of the following stock of documents. Štátny archív v Banskej Bystrici, Banská Štiavnica. Protocollum Liberae Regiae Civitatis Montanae Schemnitziensis de Annis 1725-1735; Spišský archív v Levoči. XXI. 40-42. Protocollum Regiae ac Liberae Civitatis Leuchoviensis pro Anni 1740-1750; Štátny archív v Trenčíne, KN/I 58-65, Protocollum Liberae ac Regiae Civitatis Trenchiniensis, Actorum Politicorum 1738-1743; MGTN Contractus 1560-1755; MOL E 152 Acta Jesuitica II.a. Coll. Leucsov., passim.

63 The following survey is based on Rochus Perkmann, Die Jesuiten und die Universität Wien (Leipzig: Otto Wigand, 1866); J. Wrba, "Der Orden der Gesellschaft Jesu im Alten Universitätsviertel von Wien: Hundertfünfzig Jahre von den Jesuiten geprägte Universität," in Das alte Universitätsviertel in Wien, 1385-1985, ed. Günther Hamann, Kurt Mühlberger, and Franz Skacel (Vienna: Universitätsverlag für Wissenschaft und Forschung, 1985), 2:47-74; Kurt Mühlberger, "Universität und Jesuitenkolleg in Wien: Von der Berufung des Ordens bis zum Bau des Akademischen Kollegs," in Die Jesuiten in Wien: Zur Kunst- und Kulturgeschichte der österreichischen Ordensprovinz der "Gesellschaft Jesu" im 17. und 18. Jahrhundert, ed. Herbert Karner and Werner Telesko (Vienna: Österreichische Akademie der Wissenschaften, 2003), 21-37. 
consolidated the finances. While mandatory courses had to be based on prescribed authors and readings, the religious tests for professors became less demanding, and during the next few decades Protestant professors, even rectors, were tolerated. However, as the Jesuit college reaped quick successes, obtaining the right to confer magister titles and thereby breaking the monopoly of the university, conflicts over competences remained on the agenda and were resolved in the "Klesl era" to the advantage of the Jesuits. Melchior Klesl (15521630) came from a Viennese Protestant burgher family but had a Jesuit education, was appointed as Generalreformator of the university and the region by the pope and the emperor in 1590, and as archbishop of Vienna in 1616. Though as university chancellor and then rector he took several steps that countered the Jesuits' interests, he introduced a Catholic test for all graduating students, and was the first to raise, in 1609, the idea of transferring the whole of the philosophical faculty to the Jesuits. This took place in $1622-23$ with the incorporation of the college in the university, which secured all professorial chairs in philosophy (including - pertinently for the present case-branches of mathematics) and most in theology for the Society of Jesus. The Jesuits also obtained the building of the university and several boarding houses, with the obligation to erect in their place an academic college (Collegium Academicum Viennense Societatis Jesu) with a church, theater, library, laboratory, and (later) observatory. Beginning in 1746 , they also ran the Seminarium Nobilium or Collegium Theresianum, or simply the Theresianum: an "imperial academy" launched in the framework of the reform program associated with Count Friedrich Wilhelm von Haugwitz (1702-65) as chancellor, for preparing young noblemen for entering the civil service in Vienna. But this institution remained a separate entity, much like the Oriental Academy (in its full name, Kaiserlichkönigliche Akademie für Orientalische Sprachen [Imperial and royal academy of oriental languages]), a school that offered training in Turkish, Arabic, and Persian, as well as some other skills for future diplomats in the East. It was founded in 1754 in the context of Chancellor Wenzel Anton Count KaunitzRietberg's (1711-94) general policy of administrative modernization, and also marked by a strong Jesuit presence. ${ }^{64}$

These latter developments took place in an era when, according to the standard narrative on the subject, sweeping reforms initiated by Maria Theresa's Dutch personal physician, Van Swieten, began to undermine the positions of the Jesuits at the university and, in the long run, more generally in the Habsburg

64 Given Vienna's geopolitical situation and cultural exposure to "the East," the Oriental Academy was a strategic institution. See David do Paço, L'Orient à Vienne au dix-huitième siècle (Oxford: Voltaire Foundation, 2015). 
capital, preparing the ground for the order's suppression two and a half decades later. ${ }^{65}$ Indeed, in 1749 , Van Swieten, in his capacity as director of studies at the Faculty of Medicine, implemented reforms that, thanks to their greater emphasis on bedside work and other features, not only led to the rise of the international renown of the first great Viennese medical school but with its strict application of the principle that higher education was an affair of state in every aspect from appointments through remuneration to teaching materials and so forth also provided a model of centralization during the next few years for the other faculties, too. Another important development was set in motion by the Viennese archbishop Christoph Anton Migazzi (1714-1803), who in 1758 established a Priesterseminar that exclusively employed professors who supported Jansenism. ${ }^{66}$

We have recently been cautioned that the apparent breakthrough associated with Van Swieten was neither abrupt nor smooth, and that the ascription of a quasi-heroic status to him is an aspect of the twentieth-century master narrative on "Josephism," not fully supported by, and to some extent even contravening, the sources and the earlier literature ${ }^{67}$ As a result of these processes, the dominance of the Jesuits was to some extent reduced. However, interpreting them, with the hindsight gained from the dénouement of 1773, as the beginning of an irreversible path to suppression, or a period of transition toward such an end, is probably less instructive than regarding them as what they most probably were for those affected on all sides: a program of coordination and cooperation, with a reforming and calculating government determined to optimize the allocation of resources at its disposal for the sake of greater international competitiveness (the attainment of which required efforts apparently

65 Van Swieten is the key figure in Erna Lesky, Österreichisches Gesundheitswesen im Zeitalter des aufgeklärten Absolutismus (Vienna: Rohrer, 1959); Lesky, "Gerard van Swieten: Auftrag und Erfüllung," in Gerhard van Swieten und seine Zeit, ed. Erna Lesky and Adam Wandruszka (Vienna: Böhlau, 1973), 11-62; more generally, Notker Hammerstein, "Besonderheiten der österreichischen Universitäts- und Wissenschaftsreform zur Zeit Maria Theresias und Josephs II," in Österreich im Europa der Aufklärung: Kontinuität und Zäsur in Europa zur Zeit Maria Theresias und Josephs II, ed. Richard Georg Plaschka (Vienna: Verlag der Österreichischen Akademie der Wissenschaften, 1985), 787-812; Winfried Müller, "Der Jesuitenordnung und die Aufklärung im süddeutsch-österreichischen Raum," in Klueting, Katholische Aufklärung, 225-45, here 229-33.

66 For an account of the early proponents of Jansenism in Austria and the role of Migazzi in particular, see Peter Hersche, Der Spätjansenismus in Österreich (Vienna: Verlag der Österreichischen Akademie der Wissenschaften, 1978), 50-70.

67 Sonia Horn, "Auftrag und Erfüllung: Erna Lesky and medizinhistorische Narrative im 20. Jahrhundert," in Josephinismus zwischen den Regimen. Eduard Winter, Fritz Valjavec und die zentraleuropäischen Historiographien im 20. Jahrhundert, ed. Franz Leander Fillafer and Thomas Wallnig (Vienna: Böhlau, 2016), 181-212. 
coinciding with those needed to secure the common good) ${ }^{68}$ As with other (administrative, financial, military etc.) reforms initiated by von Haugwitz and Kaunitz during the 1740 s and 1750 s, largely in response to the Habsburg monarchy's mixed performance in the War of Austrian Succession (1740-48), the university reforms targeted privilege-more precisely, privilege that ran counter to the utilitarian calculus of efficiency-but not expertise. The meritocratic considerations that inspired these steps actually favored the Society of Jesus, which not only retained control over the faculties of theology and philosophy (under which mathematics, astronomy, and experimental physics were sorted) at the university but played a key role in providing such expertise in the two new Viennese institutions of higher learning, the Theresianum and the Oriental Academy.

It would indeed have been a waste of resources to abandon Jesuit knowledge. The Jesuit professors of Vienna and other universities in the Habsburg monarchy were sufficiently competent to write textbooks (which they were required to do regularly by a 1753 decree), including one in physics that presented the controversy of Cartesian and Newtonian positions in a cogent and accessible manner - similar, for instance, to the Dissertatio physica de motu corporum (Physical Dissertation on the Motion of Bodies, Trnava, 1753) by polymath Ferenc Kéri Borgia (1702-68). Kéri Borgia had previously been the first professor to systematically cultivate astronomy at the University of Trnava in the 1730 s, to return there as rector in 1752, after serving a period of six years at the Jesuit college and thus the University of Vienna in various functions. These works obviously could not arise from rashly and newly gained knowledge, but from a confident use of discourses already available among Jesuits in the region, although difficult to bring into the public in a still ambivalent situation. While there was an urge to publish up-to-date works by the state that was arising as the supervisory authority of universities, the papal prohibition of teaching Copernicanism issued to Galileo in 1616 formally remained in force until 1757 , when it was lifted thanks to Boscovich's efforts. ${ }^{69}$ Among many other

68 For the state as a coordinating mechanism of this kind, applied to Habsburg history (in an earlier period), see Karin J. MacHardy, War, Religion, and Court Language in Habsburg Austria (Basingstoke: Palgrave Macmillan, 2002).

69 The manifestations of Jesuit reception of the new natural philosophy in Trnava are divided into two phases in Csaba Csapodi, "Newtonianizmus a nagyszombati jezsuita egyetemen," Regnum 6 (1944-46): 59-68. The textbooks written by several Trnava professors up to around 1758 testify to extensive familiarity with Newton, but with a strong preference for Descartes, while by the 1760 s Newton clearly prevailed. At that time, the fully Newtonian two-volume textbook of the Viennese Jesuit professor Karl Scherffer's (171683) Institutionum physicae [...] (1752-53) was in use in Trnava, too. Cf. Csaba Csapodi, "Két 
multi-talented Jesuit fathers on the Viennese academic and intellectual scene was Joseph Franz (Frantz [1704-76]) — mathematician, astronomer, and physicist, but also a master of oriental cultures who in the early 1740 s collected precious coins and natural objects while traveling in Asia Minor and briefly served as director of the renowned school of languages in Pera, the Latin quarter of Istanbul..$^{70}$ His published output covers areas ranging from electricity through paleontology and botany to philosophy, but he also wrote Godefridus Hierosolymitanus (Gottfried of Jerusalem [1757]), a drama performed in Latin and French as well as Turkish at the Oriental Academy, of which-no doubt because of the Pera experience-he was also appointed as the first director. In addition, he served as dean of the university's faculty of philosophy from $175^{2}$ to 1759 , and as tutor of the future emperor Joseph II (1741-90, r.1765-90), who had him buried at his personal expense. ${ }^{71}$

Kéri Borgia and Franz have been singled out from a crowd of similar figures on account of their relationship-probable in the first and ascertained in the second case - to the young Maximilian Hell during his early years in Vienna. After a consideration of the general milieu that surrounded Hell in the towns of Upper Hungary and then in the Habsburg capital, it is pertinent to attempt to construct a gallery of possible interlocutors-professors, fellow studentsin these environments. As noted above, the Jesuit houses in Banská Štiavnica, Banská Bystrica, and Levoča were relatively small establishments, but a few of Hell's teachers and colleagues even there are known as authors of theological, historical, and literary works of minor significance. ${ }^{72}$ It was during his novitiate in Trenčín that he may have first encountered figures whose stature surpassed the boundaries of the local.

The rector of the domus probationis there in these years was Ferenc Kazy (Kazi [1695-1759]), whose three-volume Historia Regni Hungariae (History of

világ határán: Fejezet a magyar felvilágosodás történetéből," Századok 79-80, no. 1 (194556): 85-137; Jolán M. Zemplén, A felvidéki fizika története 1850-ig, rev. and ed. István Gazda (Budapest: Magyar Tudománytörténeti és Egészségtudományi Egyesület, 2016 [1973]), 180-88. A previous, Slovak version of this study was published as Dejiny fyziky na Slovensku do polovice 19. storočia (Bratislava: Veda, 1974). On Scherffer, see below, 68-69.

$70 \quad$ Do Paço, L'Orient à Vienne, 27.

71 Johann Steinmayr, "Die Geschichte der Universitätssternwarte Wien," in Die Geschichte der Universitätssternwarte Wien: Dargestellt anhand ihrer Instrumente und eines Typoskripte von Johann Steinmayr, ed. Jürgen Hamel, Isolde Müller, and Thomas Posch, Acta Historica Astronomiae 38 (Frankfurt: Harri Deutsch Verlag, 2010), 169-201, here 177-78. Steinmayr (1890-1944) generally highlights the blooming of mathematical talent among the Jesuits of the Austrian province.

72 The source for this is the Jezsuita névtár; http://jezsuita.hu/nevtar/?l=J (accessed April 12, 2019), collated with data from Lukács, Catalogi personarum. 
the Kingdom of Hungary, Trnava [1739-49]) was long considered, mainly in accounts by Piarist and Protestant authors, a piece of epigonism (or worse), ${ }^{73}$ but today, together with his history of the University of Trnava (1737), it is appreciated as a respectable anticipation in methods and approach of the great Hungarian Jesuit historical school later in the century. ${ }^{74}$ Some of Hell's fellow novices in Trenčín are even more interesting. They include Adam František (Franz) Kollár (1718-83), who was in the second year of his novitiate when Hell was admitted..$^{75}$ Kollár was to play an important part in the shaping, advocacy, and implementation of Theresan enlightened reform policies. ${ }^{76}$ Like Kazy, he was also a native of northern Hungary and may have been Hell's schoolmate in the gymnasium of Banská Bystrica; his studies in philosophy at the University of Vienna in 1741-43 (and the year he spent there studying Hebrew in 1745) also partially overlapped with those of Hell. ${ }^{77} \mathrm{He}$ also began the curriculum in theology but left the Society of Jesus in 1748. In that year, his long-standing career at the Imperial and Royal Court Library began as a scribe, culminating in 1773 with his appointment as chief librarian (succeeding Van Swieten, and preceding the latter's son, Gottfried [1733-1803]). This appointment earned him the title of court councilor, in which capacity he sat on the important StudienHofkommission (court committee for science and education), responsible for the general overhaul of the education system in the Habsburg monarchy. It was also the body that adjudicated on Hell's plan for a Viennese academy of sciences in $1773-75 .^{78}$ Kollár, who had a prodigious talent for ancient and

73 Specifically, Kazy was charged with following too closely the work of Sámuel Timon (1675-1736), who in the 1720 s was the rector of the Jesuit college in Cluj, another significant venue in the early career of Hell. See, e.g., Bálint Hóman, "Tudományos történetírásunk megalapítása a XVIII. században," in Hóman, Történetírás és forráskritika (Budapest: Magyar Történelmi Társulat, 1938), 353-80, here 367-68.

74 Elréd Borián, “A történetíró jezsuita testvérek: Kazy Ferenc és Kazy János újraértékelése," Az Egyetemi Könyvtár Évkönyvei 9 (1999): 45-64. The chief figures of Jesuit historical scholarship in eighteenth-century Hungary were István Kaprinai (1714-85), György Pray (17231801), and István Katona (1732-1811), all of whom were later interlocutors for Hell in his studies of early Hungarian history.

75 Lukács, Catalogipersonarum, 8:332.

76 On Kollár, besides the slender volume of Jan Tibenský, Slovenský Sokrates: Život a dielo Adama Františka Kollára (Bratislava: Tatran, 1983), published in Hungarian as A királynó könyvtárosa: Adam František Kollár élete és müvei (Budapest: Madách, 1985), the most up-to-date and valuable piece of academic literature is a Hungarian edition of his selected correspondence, with the editor's introduction, István Soós, ed., Kollár Ádám Ferenc levelezése (Budapest: Universitas Kiadó, 2000).

77 Lukács, Catalogipersonarum, 8:528, 589, 716.

78 See below, 345-51. 
modern (including exotic) languages and coined the word "ethnology,"79 made a scholarly record in diverse fields, from inquiry into native American cultures (based on holdings of the court library) to legal and historical studies. His works in these latter fields, which were published in the 1760s, addressed a challenge to the privileges of the Hungarian nobility, based as they were on a distinctive historical ideology. These contributions made an impact on the atmosphere in which Hell's and his associate János Sajnovics's (1733-85) work on the linguistic kinship of Hungarian and "Lappish" (i.e., Sámi), and more broadly on early Hungarian history, was received in the $1770{ }^{80}$

Another fellow novice worthy of note was János Zakarjás (Zachariás [171972]), Hell's junior by one year in the Trenčín house. ${ }^{81}$ Originally from the town of Gyöngyös in central Hungary, he entered the Society of Jesus after attending the course in logic at the University of Trnava, where he returned after his probationary years to complete his studies and to teach in the gymnasium (which he then also did briefly in Esztergom). However, right upon his ordination in 1749, he applied-together with Xaver Franz Eder (Xavér Ferenc Éder [172772]), another native of Banská Štiavnica and a Trenčín and Trnava graduatefor missionary work. After completing the preparatory seminar and learning some Spanish in Córdoba, they were sent to Peru, arriving in Lima in the summer of $1751 .{ }^{82}$ Zakarjás did not leave a coherent account of his experiences, nor

79 On this aspect of Kollár's contributions, see Han T. Vermeulen, Before Boas: The Genesis of Ethnography and Ethnology in the German Enlightenment (Lincoln, NE: University of Nebraska Press, 2015), 20, 218 (referring to prompts by Tibenský, cf. n. 184).

8 o See below, 254-56, 379-87.

81 Lukács, Catalogi personarum, 8:394; http://jezsuita.hu/nevtar/zacharias-janos/ (accessed April 12, 2019).

82 Zakarjás and Eder (on the latter, see http://jezsuita.hu/nevtar/eder-x-ferenc/ [accessed April 12, 2019]) were among up to twenty eighteenth-century Jesuits from the Kingdom of Hungary active in the Indies. Another one was Ignác Szentmártonyi ([1718-93], http:// jezsuita.hu/nevtar/szentmartoni-ignac/ [accessed June 5, 2019]) who taught mathematics in Vienna during the early phase of Hell's studies in the capital and later completed his curriculum in theology there at broadly the same time as Hell (see Lukács, Catalogipersonarum, 9:43-44). Szentmártonyi joined the Brazilian mission in 1753 and carried out important cartographic work. Besides shorter and older accounts of these figures, focusing on adventurous and calamitous aspects and including Tivadar Ács, "Délamerikai magyar utazók a XVII. és XVIII. században," A Földgömb, 9 (1938): 67-74, 113-17, 150-53, and Ács, Akik elvándoroltak (Budapest: n.p., 1940), or ones in which the Jesuit presence in Latin America is embedded in a larger discussion of Hungarians in the continent, László Szabó, Magyar múlt Dél-Amerikában (1519-19oo) (Budapest: Európa, 1982); see also László Bartusz-Dobosi, "Magyar missziósok az 'Indiákon," in A magyar jezsuiták küldetése a kezdetektől napjainkig, ed. Antal Molnár (Piliscsaba: Pázmány Péter Katolikus Egyetem, 2006), 200-16. There is now a comprehensive study of those working in Brazil; see Dóra 
any academic treatise, but some of his letters - addressed to Kazy, Kéri Borgia, and another former fellow novice in Trenčín, József Bartakovics (1722-63), notable on account of his pursuits in poetry and drama ${ }^{83}$ - have been preserved. ${ }^{84}$ These provide an insight into his travels along the Andesian tributaries of the River Amazon and his work among the natives of Moxos (Mojo) province, and in a typical Jesuit fashion into the "natural and moral history" of the region. ${ }^{85}$ While most of Zakarjás's fellow Hungarian missionaries suffered severelyincluding incarceration and death-from the consequences of the suppression of the Society of Jesus in the Iberian monarchies in the late 1750 s, he managed to return to Hungary in unclear circumstances and worked as a schoolmaster and librarian in the town of Komárom (Komárno, Comaromium, Komorn) until his death in 1772.

There is no evidence of any direct contact between Hell and these figures at a later date - although, given his and Kollár's positions in the highest academic circles in Vienna over nearly thirty years between Hell's appointment and Kollár's death, in their case such contact may almost be taken for granted. Nevertheless, their profiles point to certain sensibilities in northern Hungarian Jesuit culture that are relevant to any attempt at understanding Hell's own trajectory, and vice versa: an interest in and commitment to the tradition of the ancient Hungarian monarchy and dedicating critical scholarship to its interpretation; a concomitant willingness to serve the Habsburg dynasty and the government, partly via such scholarship, in its efforts at improvement; and an openness to the wider world even at the expense of considerable physical exertion and personal hazard.

Nothing specific can be known or even conjectured about Hell's professional formation in the disciplines in which he later earned the greatest distinction, mathematics and astronomy, until his Viennese years. Upon his enrollment in

Babarczi, "Magyar jezsuiták Brazíliában a 18. század közepén" (PhD diss., University of Szeged, 2011).

83 http://jezsuita.hu/nevtar/bartakovics-jozsef/ (accessed April 12, 2019).

84 Published as "Zakarjás János és Fáy Dávid délamerikai jezsuita misszionáriusok uti levelei (1749-1756)," Földrajzi Közlemények 38 (1910): 115-28, 215-36. Eder, however, whose more robust health allowed him to travel even more widely, wrote a Descriptio provinciae Moxitarum in Regno Peruano (published posthumously in Buda in 1791, and in La Paz in 1888), still regarded as an important source for the ethnography of several isolated tribes in the region.

85 The term, of course, refers to José de Acosta's Historia natural y moral de las Indias (1590), which established the tradition of learned Jesuit travel account. On Zakarjás's contribution, see Lajos Boglár, "The Ethnographic Legacy of Eighteenth-Century Hungarian Travellers in South-America," Acta ethnographica 4, nos. 1-4 (1955): 313-59, here 323-33 (including the English translation of the letter to Kéri Borgia). 
the university, these fields were supervised there by two eminent polymaths of the Jesuit college: Erasmus Frölich (Fröhlich [1700-58]), also known for his work in numismatics and antiquarian studies, and Joseph Franz, already mentioned as the first director of the Oriental Academy but at this time still at the helm of the Viennese Jesuit Observatory, which he and Frölich had constructed at one end of the compounds of the college back in $1733-34{ }^{86}$ Franz soon recruited the young Hell to make observations there, apparently around 1743, though evidence for this is scanty. The only concrete reference to this year in this context seems to be in a letter by Hell to the Danish astronomer Thomas Bugge (1740-1815) as late as 1789: "How many strenuous works I have conducted in the service of astronomy for forty-six years of my life, ever since 1743, from which year my first observations are extant, will be talked about by future generations." 87 A manuscript biography, most probably written by Hell's successor Franz de Paula Triesnecker (1745-1817) (from 1809, von Triesnecker), gives the years "1744 and 1745," and 1745 is also mentioned in Schlichtegroll's Nekrolog of $1793 .{ }^{88}$ Around the same time, the gifted student used his spare

86 This was the second astronomical observatory in Vienna, following upon the one created with support from Emperor Charles vi by court mathematician Johann Jakob (Giovanni Jacopo) Marinoni (1676-1755) on the top of his own house in 1730 (described by contemporaries as one of the most beautiful ones in Europe). The Jesuits' self-standing "tower" was forty-five meters high, rising above the neighboring buildings by around twenty-four meters, according to Pinsker, "Der Astronom," 102; for further details, see Per Pippin Aspaas, Thomas Posch, and Isolde Müller, "Astronomische Observatorien der Jesuiten in der 'Provincia Austriae' im 18. Jahrhundert," Acta historica astronomiae 52 (2014): 89-110. In the literature, the Jesuit observatory is often confused with the Imperial Observatory established in 1755. Cf. Karl Adolf-Franz Fischer, "Jesuiten-Mathematiker in der Deutschen Assistenz bis 1773," Archivum historicum Societatis Iesu 47 (1978): 159-224; Agustín Udías, Searching the Heavens and the Earth: The History of Jesuit Observatories (Dordrecht: Kluwer Academic, 2003), 29; Gudrun Wolfschmidt, "Cultural Heritage and Architecture of Baroque Observatories," Paper delivered at the European Society for Astronomy in Culture Seventeenth Annual Meeting, SEAC 2009, 4; http://www.math.uni-hamburg.de/ spag/ign/stw/seacog-obs-barock.pdf (accessed April 12, 2019).

87 Hell in Vienna to Bugge in Copenhagen, Vienna July 24, 1789. Pinzger, Hell Miksa, 2:154. There is no primary evidence provided to support the claim that Hell was actually hired as an assistant of Franz at his observatory in 1745. Cf. Konradin Ferrari d'Occhieppo, "Maximilian Hell and Placidus Fixlmillner: Die Begründer der neueren Astronomie in Österreich," in Österreichische Naturforscher, Ärzte und Techniker, ed. Fritz Knoll (Vienna: Verlag der Gesellschaft für Natur und Technik, 1957), 27-31, here 27.

88 [Franz de Paula von Triesnecker], Lebenslauf von Hell, Österreichische Akademie der Wissenschaften, Wien, Nachlass Littrow, transcript by Hannelore and Horst Kastner-Masilko; http://kastner-masilko.at/LebenslaufHell.pdf (accessed April 12, 2019); "Maximilian Hell," in Schlichtegroll, Nekrolog, 284. The Observationes astronomicae in speculo Viennensi 173450 factae attributed to Franz might shed light on Hell's earlier career as an observer (see Heinrich Kellner, "Franz, Joseph," in Allgemeine Deutsche Biographie 7 [1878]: 318-19), but 
time to construct sun and moon dials, as well as terrestrial and celestial globes. These were probably included in the Museum Mathematicum, or laboratory of the Jesuit college, which had been founded in 1714 and occupied a lower floor underneath the observatory itself. ${ }^{89}$

Karl Scherffer (1716-83) must also be mentioned among Hell's seniors at the University of Vienna who were to play a part in his later career. A mere four years older than Hell, Scherffer-a native of Gmunden in Upper Austriaalready had a professorial career in Graz behind him when in $175^{\circ}$ he was called back to Vienna, where he had pursued his studies. The apparent reason for his recall was that as the prefect (praefectus) of the new observatory (established in 1745) as well as the laboratory in Graz he failed to obtain the money needed for modernizing the stock of instruments. ${ }^{90}$ According to some accounts, no observations at all could be made in the Graz observatory, ${ }^{91}$ which has also been described as "still-born."92 This would have been certainly unworthy of the traditions of astronomy in Graz, where Kepler had stayed in the final years of the sixteenth century, and the Jesuit Paul Guldin (1577-1643) had presented his influential theory of gravity in the 1630 s and 1640 s. Be that as it may, Scherffer earned high esteem as a professor of mathematics and physics and was a prolific author of scientific writings in Latin and German. His Institutionum Physicae Pars Prima, seu Physica Generalis and Pars Secunda, seu

we have not been able to locate this work. Cf. Aspaas, Posch, and Müller, "Astronomische Observatorien der Jesuiten."

89 Steinmayr, "Geschichte der Universitätssternwarte," 263.

9o Helmut Platzgummer, "Scherffer, Karl," in O’Neill and Domínguez, Diccionario histórico de la Compañía de Jesús 4:3519-20.

91 Constant von Wurzbach, "Karl Scherffer," in Biographisches Lexikon des Kaiserthums Oesterreich, enthaltend die Lebensskizzen der denkwürdigen Personen, welche seit 1750 in den österreichischen Kronländern geboren wurden oder darin gelebt und gewirkt haben, vols. 1-6o (Vienna: Verlag der Univeritätsbuchdruckerei/K.k. Hof- und Stadtsdruckerei, 185691), 29:214-16.

92 Johann Steinmayr, "Die alte Jesuiten-Sternwarte in Graz," ed. Isolde Müller and Thomas Posch, in Beiträge zur Astronomiegeschichte 11, ed. Wolfgang R. Dick, Hilmar W. Duerbeck, and Jürgen Hamel, Acta historica astronomiae 43 (Frankfurt: Harri Deutsch, 2011), 232-6o, here 245 . This is, however, contradicted by an undated letter of Scherffer to Franz Weiss; see Magda Vargha, ed., Correspondence de Ferenc Weiss astronome hongrois du XVIIIe siècle (Budapest: Bibliothèque de l'Université Budapest, 1990), 8-9. On the evidence of manuscripts at the Universitätsbibliothek Graz, regular astronomical observations were made in Graz in 1758-6o, 1762, and 1764-73, but some astronomical observations from the years $1746-47$ are also extant, as well as meteorological observations from the years $1754-56$ and $1760-73$. See the editors' introduction and comments on Steinmayr's study. Thanks also to Michaela Scheibl at the Universitätsbibliothek Graz for the information provided via correspondence. On Weiss, see below, 75-6. 
Physica Particularis (Introductions to physics: Part 1, general physics; Part 2, parts of physics [1752-53]) was the first to introduce Newtonianism in a physics textbook in the Habsburg lands, and was an important source (among many others) of the Graz professor Leopold Gottlieb Biwald's (1731-1805) Physica generalis and Physica particularis (General physics; Parts of physics [1767-68]), which, in turn, were influential across Europe. ${ }^{93}$ Scherffer also remained very active in the Viennese astronomical community during Hell's tenure as imperial and royal astronomer, chiefly on the theoretical side, as demonstrated by his Institutiones astronomiae theoreticae (Introductions to theoretical astronomy [1777]). ${ }^{94}$

In 1745 , Hell had his first (anonymous) work published. The Elementa arithmeticae numericae et literalis, exposita a Joanne Crivellio (Elements of numerical and literal arithmetics, explained by Joannes Crivelli) is the "third, corrected" edition of a textbook by the Venetian mathematician and priest Giovanni Francesco Crivelli (1690-1743), originally published in Italian in 1728 and then in Latin in 1740. In some of the literature on Hell, this volume is referred to by the title Elementa algebrae Joannis Crivelli magis illustrata et novis demonstrationibus et problematibus aucta (Elements of algebra by Joannes Crivelli, illustrated and expanded by new demonstrations and problems), and it is claimed that the "further explanations and expansions by new demonstrations and exercises" indicated in the title were considerable. ${ }^{95}$ In the copy available to us (bearing the former title), this cannot be ascertained. Hell took the previous Latin edition of 1740 and-according to his short addition to the editorial preface - confined himself to "emending dubious Latin phrases by supplanting them with new ones that are both clearer and especially accommodated to

93 Cornelia Faustmann, "In parte physicae theoretica Newtonum eiusque commentators secutus sum': Leopold Gottlieb Biwald's Physica generalis as a Compendium Propagating Newtonian Physics in Europe," in The Circulation of Science and Technology: Proceedings of the 4 th International Conference of the ESHS in Barcelona, 18-20 November 2010, ed. Antoni Roca-Rosell (Barcelona: SCHCT-IEC, 2012), 349-54, and Faustmann, "Physik des 18. Jahrhunderts im Spiegel der Quellen” (PhD diss., University of Vienna, 2010).

94 It is noteworthy that while this work contains many references to great contemporary astronomers like Lalande, Lacaille, Halley, Boscovich, and so forth, none of Scherffer's peers in Vienna are acknowledged. Despite treating topics in which Hell ought to be considered an expert, he makes no reference to him: when mentioning, for instance, the socalled satellite of Venus, he presents in brief the same explanation as Hell had used in his treatment of the subject, but without any reference. Karl Scherffer, Institutiones astronomiae theoreticae (Vienna: Trattner, 1777), 8. Similarly, while a brief section is devoted to "De transitu Veneris, vel Mercurii infra discum Solis," he only quotes Lalande as an authority. Scherffer, Institutiones astronomiae theoreticae, 391.

95 Pinsker, "Der Astronom," 103-4. Elementa algebrae is also the title mentioned in Sommervogel, "Hell," 250. 
the needs of beginners. Freed from its typographical errors, we hereby present this work to readers eagerly wishing to learn this highly useful science." ${ }^{96}$ What is important to note is that in the summary of the progress of mathematics provided in the author's introduction to both editions, Crivelli firmly aligns himself with the moderns, mentioning Cartesian algebra and the invention of infinitesimal calculus (attributed by him to Leibniz) in a tone of high appreciation. ${ }^{97}$ Hell apparently had no reason to dissent. To further locate Crivelli and his oeuvre, his Elementi di fisica (Elements of physics [1731; revised edition 1744]) should be mentioned, too: he closely follows Newton in all branches of physics from optics to astronomy, and in the enunciation of phenomena from colors through gravity to ebbs and tides, and speaks of Galileo as "the prince of scientists." 98

The first edition of another anonymous work, titled Adjumentum memoriae manuale chronologico-genealogico-historicum was also published by Hell in 1750. This "manual of chronology, genealogy, and history for the assistance of memory" consisted of thematically arranged lists of important names and events of sacred and profane history (biblical figures, popes, religious orders; rulers of European states, major battles, and peace treaties) that went through ten editions; the final (posthumous) revision was published in $1802 .{ }^{99}$ The Adjumentum was a pedagogical exercise, and he had other ample opportunities to test and improve his skills in this regard in several other ways during his Viennese years. Already as a student of philosophy, he was appointed manducator, a kind of supervisor of his peers; when he returned to the university for the course in theology in 1748 , he was at first bidellus concionum et tonorum, that is, an assistant chairing test sermons and lectures, and then in his upper years the prefect of the students of theology in the Collegium Pazmanianum

96 [Giovanni Francesco Crivelli], Elementa arithmeticae numericae et litteralis exposita a Joanne Crivellio, C.R.S. Academiae Bononiensis Academico Honorario, et Regiae Societatis Londinensis Socio: Editio tertia, prioribus correctior (Vienna: Kaliwoda, 1745), 10. Cf. Crivelli, Elementa arithmeticae numericae et litteralis exposita a Joanne Cribello (Venice: Lazzaroni, 1740), vii.

97 [Crivelli], Elementa arithmeticae (1740), xii; [Crivelli], Elementa arithmeticae (1745), 7.

98 As the text of Elementi di fisica, esposti dal p. d. Giovanni Crivelli: S'aggiungono dell' istesso autore due dissertazioni Sulle leggi del moto, e Dell'estimazione delle forze vive, ed I problemi aritmetici di Diofanto Alessandrino analiticamente dimostrati (Venice: Baglioni, 1744) is available in searchable form at https://babel.hathitrust.org (accessed April 12, 2019), it is easy to identify a total of no fewer than forty references to Newton by name. The appreciation of Galileo (also earning twenty-nine mentions by name) is on p. 15 .

99 Hell kept this work anonymous until he made a revision of it in 1773, published in Vienna in the following year. 
(or shortly the Pazmaneum), a seminary established in 1623 to train Catholic priests and still in the management of the Society of Jesus. ${ }^{100}$

A different kind of pedagogical experience creates, remarkably, a bridge between Hell's descent from the mining region and a family of widely recognized mining experts and his formation in the Habsburg capital at the time of the first wave of "enlightened" reforms pursued by the government. According to some accounts, he came in contact with the aristocratic Königsegg family in the mid-1740s (either as an upper-grade philosophy student in Vienna, or while in Levoča), and he even offered instruction in mathematics and Markscheidekunst (mine metrology) to a young member of the family destined for a career (probably in the mining chamber) in Banská Štiavnica. ${ }^{101}$ After his return to Vienna in late 1747 , Hell is said to have received several assignments from "Count Königsegg." The Königsegg count in point can be no other than Karl Ferdinand (1696-1759), who after an initial career in the Catholic Church laid down his cassock and embarked on a quite spectacular period of diplomatic service, culminating in the position of vice-president of the Council of the Austrian Netherlands. In 1748, shortly after his return to Vienna, he was appointed president of the Münz- und Bergwesens-Directions-Hof-Collegiums, a newly created authority to supervise the affairs of mints and mines, separated from the Imperial Court Chamber (besides being placed at the helm of the court committee for the southeastern regions of the Banat and Illyria). ${ }^{102}$ These appointments show that Königsegg, characterized by contemporaries

100 Lukács, Catalogi personarum, 8:526, 9:44.

101 [Von Triesnecker], Lebenslauf, 1; "Maximilian Hell," in Schlichtegroll, Nekrolog, 284-85; Carl Ludwig Littrow, P. Hell's Reise nach Wardoe bei Lappland und seine Beobachtung des Venus-Durchganges im Jahre 1769: Aus den aufgefundenen Tagebüchern geschöpft und mit Erläuterungen begleitet (Vienna: Gerold, 1835), 4; Pinzger, Hell Miksa, 1:14. The latter two are obviously based on the former ones.

102 Gerhard Seewann, "Königsegg-Erps, Karl Ferdinand Graf," in Biographisches Lexikon zur Geschichte Südosteuropas, ed. Mathias Bernath and Felix von Schroeder (Munich: Oldenbourg, 1976), 2:453-54. For the identification of Königsegg as Hell's contact, see Ansgar Rabenalt, "Astronomische Forschung im 18. Jahrhundert in Kremsmünster: Zu den ersten Berechnungen der Bahn des Uranus nach dem Briefwechsel zwischen Placidus Fixlmillner O.S.B. and Maximilian Hell S.J. (1771-1790)," Mitteilungen des Oberösterreichischen Landesarchivs 15 (1986): 93-216, here 109. On the context of the general overhaul of the administrative system during the first years of Maria Theresa, see Klaas van Gelder, "Networks, Agency, and Policy: A New Approach to Maria Theresa's Advisors during the War of the Austrian Succession," in Maria Theresia? Neue Perspektiven Der Forschung, ed. Thomas Wallnig, Elisabeth Lobenwein, and Franz-Stefan Seitschek, Das achtzehnte Jahrhundert: Jahrbuch der Österreichischen Gesellschaft zur Erforschung des 18. Jahrhunderts 32 (Bochum: Dr. Dieter Winkler Verlag, 2017), 151-70. 
as an outstanding administrator, was intended to play an important part in the ongoing overhaul of the economic foundations of the Austrian state.

It is tempting to interpret the alleged delegation of relevant tasks to the young scion of experts with local knowledge in the mining district - who at the same time was a budding scientific genius - as a sign of selection with discerning eyes, and without any anti-Jesuit prejudice, on the part of the enlightened government. It may even be the case that Jesuit patronage played a part: the many functions held by Hell's teacher and mentor Franz at this time included Bergrath (i.e., senior official overseeing the mining industry). If all of this was indeed the case, Hell the "expert" had been discovered as an asset by the Viennese government well before his merits as a "scientist" were rewarded by the appointment of 1755 , and the early discovery may even have played a part in the later appointment — while it must be added that a sharp distinction between expertise and science is meaningless in eighteenth-century contexts, as has been argued (significantly, given the contours of Hell's lineage) on the example of Leibniz's engagement of the problem of draining the Harz silver mines by relying on wind machines. ${ }^{103}$

Some caution regarding Hell's association with the Königsegg family is justified, though, as reports about it derive from accounts of Hell's life and career conceived shortly after his death (i.e., several decades after the event). One of these accounts was conceived by a colleague working with him closely for many years. Unfortunately, neither of them is corroborated by any testimony by Hell himself, nor any archival documents in the otherwise rich and wellkept holdings of the Department of Mints and Mines in Vienna. ${ }^{104}$ In any case, according to these posterior reports, the tasks assigned to him included further courses in mathematics and Markscheidekunst, now to a group of ten young noblemen in preparation for work in the mining industry in Hungary, and even the translation of the laws of the mining industry from German into Latin. ${ }^{105}$ What exact purpose such a translation was to serve is not clear-but given that

103 The futility of Leibniz's efforts to provide a "scientifically based" solution to the problem has been generally explained with reference to the resistance of "experts" in the Hanoverian mining administration, but this is more likely to have emerged out of struggles in the state. See Andre Wakefield, "Leibniz and the Wind Machines," Osiris 25 (2010): 171-88.

104 At the same time, these holdings contain ample references (even from the years of Maximilian's supposed collaboration with Königsegg) to Hell's father and brothers, the subjects ranging from the application of inventions through payment requests to inheritance issues. Österreichisches Staatsarchiv (ÖStA), Finanz- und Hofkammerarchiv, Neue Hofkammer, Akten Altes Münz- und Bergwesen, Chronologische Reihe, 1747-56.

105 See above, n. 101. The translation is only mentioned in the Nekrolog, where it is also claimed that the manuscript was delivered to Franz in 1749, but apparently was never published. 
he came from a family of engineers and was fluent in Latin, which he had acquired in the Jesuit schools, Hell was certainly well suited for carrying it out.

Finally, in a roll-call of figures and possible encounters that link Hell's years of study in Vienna and his background around the mines of Banská Štiavnica, mention must be made of Nikolaus Poda (Boda, or Poda von Neuhaus [172398]), already referred to briefly. ${ }^{106}$ Poda, the scion of a Tyrolean noble family but a native of Vienna who joined the Society of Jesus in 1740 and pursued his studies in philosophy in Klagenfurt, returned to the capital for the course in mathematics in 1748 (when Hell did the same in order to begin the theology curriculum), and became a first-year student of theology (theologus primianni) when Hell was in his third year in $1750^{0 .}{ }^{107}$ As we shall later see in more detail, whether or not they were in contact at the university, they cultivated relatively strong ties later on. Ordained in $175^{2}$, Poda then taught mathematics, mechanics, and hydraulics (but also developed a strong interest in entomology, mineralogy, and paleontology) in Klagenfurt, Linz, and Graz, and was the director of the observatory in Graz, before his appointment at the mining school in Banská Štiavnica in 1765 . He was a professor of mine metrology, mechanics, and engineering there, also producing mechanical models and publishing works with descriptions and images of machines used in the local mines-namely those constructed by Hell's father and brother. In doing so, Poda apparently violated regulations requiring the express permission of the authorities for mines and mints for the publication of such images (after all, industrial secrets were at stake). ${ }^{108}$ This may have been the cause for his untimely retirement in 1772 to the Abbey of Traunkirchen, where he devoted himself to the completion of his textbook on mechanics. In the turmoil caused by the Society's suppression in 1773, this work remained unpublished. Like others in the same position, Poda then maintained himself as a secular priest who also gave private lessons in the fields of his expertise, while he was also active in the scientific and freemasonic circles around von Born, whom he had known well from his Banská Štiavnica years. ${ }^{109}$

Several types are emerging from the present scrutiny as populating the social and intellectual universe of Hell as a rising star of an important chapter in the history of the Habsburg-Jesuit liaison. They include metropolitan

\footnotetext{
$106 \quad$ See $n n .35$ and 42 above.

107 Lukács, Catalogi personarum, 9:44, 175.

108 Helmut W. Flügel, "Nikolaus Poda und die mineralogisch-paläontologische Sammlung der Jesuitenuniversität Graz von 1766," Joannea Mineralogie 3 (2006): 25-61, here 31-32.

109 Von Born played a part in the publication of Poda's Kurzgefaßte Beschreibung (cf. n. 35), and Poda participated in the international meeting for miners, metallurgists, and naturalists in Skleno in 1786, mentioned above.
} 
professors (Kéri Borgia, Frölich, Franz, Kollár), some of them flamboyant, charismatic polymaths aligned with the projects of improvement launched by the Viennese government; aristocratic promoters of such projects themselves (Königsegg); scholars, teachers, and institutional leaders working in more modest localities, whose cultural (Kazy) and/or economic (Poda) significance nevertheless pointed way beyond the confines of those localities; and vagabonds defying the perils of traversing distant seas and lands for the sake of the greater glory of God, the saving of souls, and the progress of knowledge (Zakarjás). Most of the many individuals to be encountered as we follow the later phases of his career can be reduced to one of these types.

Hell's own trajectory led him to assume the character of most of these types in turns, occasionally even more than one of them at the same time. For the time being, having completed the curriculum in theology and been ordained a priest of the Society of Jesus in 1751, he continued his career in the Jesuit centers of the Hungarian provinces. First, he passed his obligatory third year of probation in Banská Bystrica, one of the two places in the Austrian province where this could be done (the other being Judenburg in Styria). ${ }^{110}$ Once finished with the probation, in the summer and autumn of $175^{2}$ Hell was briefly involved as a consultant for the construction of an astronomical observatory at the University of Trnava, an indication of his growing reputation in the field. ${ }^{111}$

By this time, Trnava boasted some traditions in astronomical studies and observations, going back to the seventeenth century, ${ }^{112}$ although, as mentioned, it was Kéri Borgia during his first stay there in $1735^{-} 36$ who began to devote systematic attention to the subject, including the construction of instruments that were later also used elsewhere in Europe. ${ }^{113}$ The idea of establishing an observatory originated with him, too. In many accounts, Hell is credited with planning and supervising the construction of the observatory, but all

110 Lukács, Catalogipersonarum, 9:289-90. Some of the literature mentions Žilina, while Döbrentei gives Zvolen (Zólyom, Altsohl), but there was no domus probationis at either of these places.

111 For a comprehensive account of the establishment and history of the observatory, see Alžbeta Hološová and Henrieta Žažová, History of the Observatory at the University of Trnava (Trnava: Trnavská Univerzita, 2013).

112 Farkas Gábor Kiss, "Johann Misch Astrophilus Nagyszombaton," Magyar Könyvszemle 121, no. 2 (2005): 140-66; Lajos Bartha, "A nagyszombati egyetem csillagvizsgálójának kezdetei," Padeu 16 (2006): 8-38, here 11.

113 In the present context, it is interesting to note that Kéri Borgia's "scientific productions" are mentioned by Zakarjás in a letter of June 15, 1749 as part of the rich equipment seen at the University of Cádiz. "Zakariás János és Fáy Dávid," 125. While in Trnava, Kéri Borgia also published a Dissertatio astronomica de cometa viso 1729 et 1730 (1736). Cf. Bartha, "A nagyszombati egyetem," 11-12. 
he himself ever claimed was an advisory role. ${ }^{114}$ The real initiator and founder was Kéri Borgia, according to the assessment of contemporaries: "Only Hungary had never seen anything like this until the year 1755, when Franciscus Kéri Borgia, worthy of memorialization by posterity, constructed for Urania a home in Trnava, and a perfect one in every aspect," wrote János Sajnovics, who served as an assistant astronomer in Trnava in 1766-68 and again in 1770-73 (preceded and interrupted by periods of performing the same function on the side of Hell, first in Vienna, and then on the Arctic expedition). ${ }^{115}$

While Kéri Borgia was also appointed as associate prefect (socius praefectus) of the new observatory, its direction, including its equipment, was entrusted to Xaver Franz Weiss (1717-85). ${ }^{116}$ Born in Trnava, Weiss joined the Society of Jesus in 1733 and studied at the universities of his native town (philosophy) as well as Graz (theology). Between the two, from 1741 to 1745 , he switched from one gymnasium in northern Hungary to the other each year teaching "humanities" (humaniora). It was during the years in Graz-at a Jesuit university with an observatory since exactly 1745 - that he may have developed an interest and expertise in astronomy, to which his correspondence in $175^{\circ}$ (while on his third probation in Judenburg) with Scherffer (at that time, the director of the Graz observatory) testifies. ${ }^{117}$ One of these letters also demonstrates that Weiss contemplated an expedition to Brazil during this time. From Scherffer's advice on how to proceed, it emerges that this was meant to be an expedition in the style of the geodetic surveys by Maupertuis in the Torne River Valley and La Condamine in the territory of Quito in the 1730 s. ${ }^{118}$ Nothing came of the plans for a

114 Cf. the letter to Bugge, already mentioned, in Pinzger, Hell Miksa, 2:154.

115 Joannes Sajnovics, Idea astronomiae, honoribus regiae universitatis Budensis dicata (Buda: Landerer, 1778), 6. Given the roles Sajnovics played in Hell's projects as imperial and royal astronomer, he will be introduced in more detail later.

116 For a biographical sketch, see http://jezsuita.hu/nevtar/weiss-ferenc/ (accessed April 12, 2019).

117 Scherffer to Weiss, Graz, August 29, 1750, in Correspondence de Ferenc Weiss, 1:13. "I wished to describe this to His Reverence [i.e., Weiss] before he leaves Judenburg: If something similar (which I doubt not, as long as the skies were clear) was seen there, please describe it." The preceding part of the letter describes an aurora borealis seen in Graz on August 26.

118 Scherffer to Weiss, Graz, August 2, 1750, Correspondence de Ferenc Weiss, 10-11. In 1750, King João V of Portugal (1689-1750, r.1706-50), in the aftermath of a treaty signed with Spain concerning their Latin American territories, had asked the general of the Jesuit order for ten Jesuits to be sent to map his dominions in Brazil. (Szentmártonyi, mentioned in $\mathrm{n} .82$ above, eventually became one of these.) Boscovich—soon to acquire fame for his survey of the papal lands, which included a measurement of the meridian between Rome and Rimini in collaboration with the English Jesuit Christophe Maire (1697-1767) also hoped initially to go to Brazil for the same purpose. See Elizabeth Hill, "Roger Boscovich: A Biographical Essay," in Roger Joseph Boscovich S.J., F.R.S., 1711-1787: Studies of His Life and 
Brazilian expedition, however, and in the university year $175^{2-53}$, when Hell was present as a consultant for the planning of the observatory, Weiss was appointed professor of mathematics in Trnava. While there, he also wrote the first unequivocally Newtonian textbook in astronomy in Hungary, Astronomiae physicae juxta Newtoni principia breviarium (A short introduction to physical astronomy according to the Principia of Newton [1759]). An astronomical almanac, reporting on observations in Trnava (Observationes astronomicae [...] in observatorio Collegii Academici Societatis Jesu Tyrnaviae in Hungaria habitae [Astronomical observations made in the observatory of the Jesuit collegium of the academy of the Society of Jesus in Trnava in Hungary (1759-72); covering the years $175^{6-71]}$ ), was also launched by Weiss, whose correspondence reveals him to have been widely connected and recognized among fellow astronomers and mathematicians all over Europe. He maintained a lifelong professional relationship with Hell - mostly also via correspondence, as by the time the foundation stone of the Trnava observatory was ceremoniously laid on January 2 , 1753, Hell was already established in his next position as professor of mathematics, also commissioned with the creation of an observatory, at the Jesuit academy in Cluj.

\section{4}

\section{Professor on the Frontier}

With the transfer to Cluj, Hell moved to a Habsburg province that was altogether a far cry from those known to him from the times of his upbringing and studies. Like Upper Hungary, Transylvania was multi-ethnic and multiconfessional, but the parallels ceased there. Already in the Middle Ages, the region was under separate governance with its own governor (vajda or voivode) and provincial assembly. From the rise of the Principality of Transylvania after the Battle of Mohács in 1526, this became an independent diet, in which the three privileged groups: Hungarian nobles, Szekel freemen, and "Saxon" burghers were represented. The Szekels (székelyek, siculi), concentrated in the easternmost areas of Transylvania, were Hungarian-speakers who preserved a separate identity on account of the tasks they performed in warfare, especially as border guards, and the consequent peculiarities of social organization and hierarchy; while Saxons were predominantly town-dwellers, migrating to the Kingdom of Hungary as hospites from various parts of Germany in several waves since the twelfth century. The most (and increasingly) numerous among the several other ethnic groups living in Transylvania were the Romanians,

Work on the 25oth Anniversary of His Birth, ed. Lancelot Law Whyte (London: Allen \& Unwin, 1961), 16-101, here 25-27. 
who, apart from a few notable exceptions who managed to gain Hungarian noble status and a small literate elite of Orthodox Christian priests, were peasants or shepherds, and thus remained outside the estates structure. There was a marked presence of Roma ("gypsies") from the sixteenth and Armenians from the seventeenth century; Jews began to appear in the early seventeenth century, and by the eighteenth century there were also Muslims of varied ethnic background as "remnants" of the Ottoman era.

Thanks mainly to the predominantly Orthodox Romanians, Transylvania had been accustomed to denominational diversity well before the Protestant Reformation, which was embraced there eagerly. Lutheranism was the favored brand in the Saxon towns, while many among the Hungarian elite as well as commoners had converted to Calvinism by the $1560 s$. The teachings of antiTrinitarians (called Unitarians in the region) and even more radical sects fell on fertile ground, too. Adherence to Protestantism also accentuated the distinctiveness of Transylvania as a political unit from the 1540s onward, when the part of the Hungarian nobility that refused to acknowledge the claim of the Habsburgs to the throne of Hungary managed to establish it as an independent principality under rulers elected from its own ranks. Among these, over a century and a half it was only the Báthoris at the turn of the sixteenth and seventeenth centuries that were Catholic; and although the practice of religious freedom, famously enshrined (at least for the four main western Christian denominations) in law in 1568 , had its ups and downs, the sometimes venomous disputes went with less physical violence and administrative infringement than in most other countries of Europe.

To further nuance the picture, all of this took place in a region at the southeastern fringe of the Western world that was, despite its richness in mineral resources and the fact that it profited from the land route of Levantine trade between the Black Sea and the Baltic, socially and economically somewhat backward. The appeal that Protestantism had there for a thin literate elite largely consisted in the encouragement and boost it gave to the cultivation of vernacular culture(s), perceived as wedged between two conquering empires. In the negotiations dictated by this geopolitical and geo-cultural position, Transylvania sometimes drifted close to being a mere Ottoman satellite; and while the turbulence and frequency of its seventeenth-century diets had more in common with an archaic kind of anarchy than modern parliamentarianism, the exertions of princely authority also resembled "oriental despotism" as much as they had features of administrative centralization familiar from histories of state-building in early modern Europe. ${ }^{119}$

119 For overviews and assessments of the history of Transylvania in the early modern period, especially the age of the independent principality, see Ştefan Pascu, A History of 
The demise of the independent Principality of Transylvania in the turmoil of the wars that led to the expulsion of the Ottomans from Hungary has already been mentioned briefly above. From the Habsburg vantage point, this reconquista implied the task of integrating the vast newly gained territories with their already extensive composite monarchy politically, economically, and culturally. Although the Diploma Leopoldinum of $1690^{120}$ stipulated the maintenance of the religious status quo in Transylvania, Catholic mission, naturally with a prominent role assigned to the Society of Jesus, was central to this vast enterprise: despite differences in emphasis, the Habsburg endeavor of consolidating the dynasty's hold over a somewhat exotic fringe area was compatible with the Jesuits' striving for the conversion of souls in obscure and contested locations (whether in Europe or overseas). ${ }^{121}$ After their 1607 expulsion, Jesuit presence in the region can still be documented quite extensively: the staunchly Calvinist but deeply pragmatic prince Gábor Bethlen (1580-1629, r.1613-29) allowed a handful of Jesuits to return for a new Transylvanian mission, and the Society could also operate some schools, either openly, or formally

Transylvania (Detroit, MI: Wayne University State Press, 1982), 96-129; Béla Köpeczi, László Makkai, András Mócsy and Zoltán Szász, with Gábor Barta, eds., History of Transylvania (Budapest: Akadémiai Kiadó, 1994), part 3, 247-311. Cf. also László Kürti, The Remote Borderland: Transylvania in the Hungarian Imagination (Albany, NY: SUNY Press, 2001), 1-24, on Transylvania as a bridge between supposedly "advanced" Austria-Hungary and the "backward" East. For assessments of the political status and system of Transylvania, see Teréz Oborni, "Between Vienna and Constantinople: Notes on the Legal Status of the Principality of Transylvania," in The European Tributary States of the Ottoman Empire in the Sixteenth and Seventeenth Centuries, ed. Gábor Kármán and Lovro Kunčević (Leiden: Brill, 2013), 67-89; Gábor Kármán, "The Hardship of Being an Ottoman Tributary: Transylvania at the Peace Congress of Westphalia," in Frieden und Konfliktmanagement in interkulturellen Räumen: Das Osmanische Reich und die Habsburgermonarchie in der Frühen Neuzeit, ed. Arno Strohmeyer and Norbert Spannenberger (Stuttgart: Franz Steiner Verlag, 2013), 163-83.

120 This constitutional document settled the status of Transylvania as a province directly dependent on Vienna, thus separated from the rest of the Kingdom of Hungary, autonomous in its internal affairs as a principality under a Habsburg governor. In 1765, Transylvania was raised to the status of Grand Principality.

121 Cf. Jean Nouzille, "Les jésuites en Transylvanie au XVII ${ }^{\mathrm{e}}$ et XVIII siècles," XVII ${ }^{e}$ siècle: Revue trimestrielle 50, no. 3 (1998): 315-28; Shore, Jesuits and the Politics of Religious Pluralism, 8. On the central role of "baroque" in Habsburg state-building, especially as regards the integration of the territories obtained after 1526, more generally see R.J.W. [Robert John Weston] Evans, The Making of the Habsburg Monarchy, 1550-1700: An Interpretation (Oxford: Oxford University Press, 1979); Evans, Austria, Hungary and the Habsburgs, especially $3^{-16,36-74 .}$ 
under the auspices of local parishes. ${ }^{122}$ Nevertheless, a full-scale reinstatement did not occur until 1693, when - thanks to funds from Emperor Leopold I, soon followed by many local Catholic dignitaries ${ }^{123}$ — the Society was able to embark on a systematic program of proselytization via schooling, charitable activities, aesthetic and spiritual appeal, and the redefinition of the urban landscape. Cluj - a town of a mere eight-thousand inhabitants, but still the most important urban and administrative center in the region-was to play a central part in the program's execution.

As far as the strictly religious goals are concerned, the Jesuit record in eighteenth-century Cluj was mixed. Conversion rates remained modest, and even the Uniate (or Greek Catholic) Church—which was established in 1692 and existed "in union" with the pope but retained an eastern liturgy-attracted far fewer Orthodox Romanians than originally hoped. ${ }^{124}$ Besides interdenominational tensions, the Jesuits evoked the resentment of the secular wing of the local Catholic clergy, too. A stormy controversy occurred in 1754 (i.e., exactly during the time Hell spent in Cluj), when complaints were raised about the "arrogance" and "insolence" of the Jesuits, and about various kinds of "usurpations" by them, whether of jurisdictional rights over monasteries around the town, or of the administering of parish duties, specifically to military personnel. In his defense, Rector András Gál (dates unknown) expressed his respect for Transylvanian bishop Zsigmond Antal Sztojka (dates unknown), but referred to privileges granted by Pope Gregory XIII (1502-85, r.1572-85) to the rector of the Jesuit college in its ancient founding document. He also alleged that the monasteries in question had never been subject to the diocese, but only directly to the archbishop of Esztergom, and stated that the administration of religious services in the army had been bestowed on the Society of Jesus by the capellanus major castrensis (chief military chaplain of the imperial troops, effectively with episcopal powers). In fact, the holder of that office, the influential Viennese Jesuit Ignaz Kampmiller (1693-1777) — also Maria Theresa's confessor-had already written to Sztojka in consternation. Kampmiller, allegedly with support from her majesty, which he had sought in an audience, urged the bishop to retreat on his moves against the rector, referring to the utmost importance of restoring peace and harmony, "especially in those territories, where the number of heretics is so substantial." Nevertheless, Sztojka persevered, rejecting the rector's arguments and even issuing threats of

\footnotetext{
122 Júlia Varga, “Katolikus közép- és felsőoktatás Erdélyben a 17. századtól a 19. század közepéig" (PhD diss., Budapest, Eötvös Loránd University, 2007), 62-92.

123 Varga, "Katolikus közép- és felsőoktatás Erdélyben," 112-15.

124 Shore, Jesuits and the Politics of Religious Pluralism, 27-88.
} 
excommunication to Gál, and eventually it was the latter who felt forced to retreat. ${ }^{125}$

Though this affair and its outcome, which must have seemed unusual for a man with Hell's stock of experience, might be taken as a confirmation of the familiar narrative of the decline of Jesuit influence in the mid-eighteenth century, the Society's visibility and impact in Cluj was striking. As the town was small and had been architecturally rather static since the late Middle Ages, the building complex erected in its center under Jesuit auspices, dedicated to educational, religious, and secular purposes, exerted a transformative effect beyond its relatively modest scale. Its consistent use of the conventions of baroque emphasized the Jesuit commitment to a universalist vision whose geographically closest local idiom found expression in Vienna: a function of the "Jesuit district" in Cluj was to make it "look more Austrian, less individual, less 'ethnic', and more rationally organized," and thus to tip the precarious balance between east and west that existed in the town toward the latter. ${ }^{126}$ This Jesuit vision also penetrated the daily lives of town-dwellers from the elite to the marginalized, thanks to the Society's participation in the mechanisms of social ordering through ritual, example, and injunction. Practices of penance, drama performances, the inculcation of values of "propriety" in a range of institutions like the orphanage or the religious sodalities set up by the Society offered a rich storehouse of devices, making it possible to correct and control irregular, socially harmful practices from dueling through sexual license and polygamy to outrageous conduct and "superstition."127

As a matter of fact, the characteristic terrain where such Jesuit antidotes to social ills-easily aligned with the "enlightened" quest of subjecting the passions to the governance of reason in the interest of harmony and happinessworked, was urban, and the very thinness of the urban fabric in Transylvania set limits to their effectiveness. The domain where the eighteenth-century Jesuits of Cluj were probably most unequivocally successful is itself typically

125 The complaints are developed in letters by Sztojka addressed to the Cluj college (Cluj, January 16, 1754; Sibiu, February 22, 1754) and a report by Cluj chaplains Péter Ferendi and Ferenc Nagy (March 6, 1754). The intervention of the capellanus major is contained in Kampmiller to Sztojka, Vienna, February 5, 1754, while Gál's defense was made in a responsio dated March 20, 1754. The conclusion of the affair is documented in Sztojka's letters of August 14, 1754 "to the beloved clergy and to the beloved, pious population of both sexes, in the free and royal city of Cluj," as well as specifically to parish priest János Bíró, and the record of a meeting between Sztojka and Gál on August 24, 1754. Cluj, Archives of the Parish of St. Michael, 36, 99-107.

126 Shore, Jesuits and the Politics of Religious Pluralism, 111-17.

127 Shore, Jesuits and the Politics of Religious Pluralism, 147-62. 
urban: education, where they covered the full spectrum with two boys' schools, a seminary and a convent for nobles (convictus nobiliorum), a gymnasium, and especially the academy, which was re-established in $1698 .{ }^{128}$ Originally confined to a single faculty of philosophy, the academy obtained a faculty of theology as well in 1712. The number of students in the college grew steadily (from fifty in 1703 and 186 in 1711, to 387 in 1747,427 in 1753 , and 493 in 1771), ${ }^{129}$ as did academic prestige: in 1753, shortly after Hell's arrival, the official designation of the institution changed from Collegium Academicum to Alma Universitas, that is, a university proper. Besides being a training ground for future Jesuits, the college offered cultural goods of a broad appeal way beyond the boundaries of the Catholic community. The curriculum underwent several waves of ambitious innovations, so that advanced students could pursue topics in the natural sciences, post-Ptolemaic astronomy was cultivated, historical studieswith a healthy equilibrium of extolling patriotic virtues and the prestige of the Habsburgs - became established, and Hebrew took its place alongside Latin and Greek in the study of classical languages. ${ }^{130}$ To support these developments, the college maintained a library with holdings that grew from about one thousand to six thousand between the beginning of the eighteenth century and the suppression of the Society, containing an impressive number of titles in modern natural philosophy and other secular fields. ${ }^{131}$ From 1726 on, it also made room for a printing press, which until 1773 issued 353 works in Latin as well as the local vernaculars, mainly textbooks for the regional schools and religious literature, but also works relevant to enlightened improvement in the economy and the polity. ${ }^{132}$ All of this made the Cluj academy a highly distinctive institution and enabled it to compete successfully with the prestigious Calvinist higher schools of the region in attracting even non-Catholic students.

Thus, in late $175^{2}$, Maximilian Hell arrived in a peripheral but vibrant sociocultural and academic setting, where the stakes of cultivating the values of Jesuit science at a high-level of professionalism were significant, even though different from other far-away missionary outposts like China, where the influence earned by impressing the emperor and a small circle of court mandarins

\footnotetext{
128 On the academy generally, see Vencel Bíró, $A$ kolozsvári jezsuita egyetem szervezete és épitkezései a XVIII. században (Kolozsvár: Erdélyi Múzeum Egyesület, 1945); Varga, "Katolikus közép- és felsőoktatás Erdélyben," 111-63.

129 Bíró, A kolozsvári jezsuita egyetem, 7 (based on the college registers).

130 Shore, Jesuits and the Politics of Religious Pluralism, 92, 94, 106.

131 Lajos György, A kolozsvári római katolikus Lyceum-könyvtár története 1579-1948 (Budapest: Argumentum Kiadó, 1994), 55-78.

132 Varga, "Katolikus közép- és felsőoktatás," 119.
} 
with tokens of European technological advancement and mathematicalastronomical prowess also secured penetration in the rank-and-file of a centrally dominated social hierarchy. ${ }^{133}$ Indeed, Hell, who spent less than three full years in Cluj, was the only one among the Jesuits active there who ever made a mark in scholarship, if we disregard János Frivaldszky (1730-84). Frivaldszky was an eclectic professor of philosophy and mathematics, as well as librarian and historian of the house and co-founder of the Transylvanian Society for Agriculture. His published work ranged from pioneering dissertations on iron ore and the minerals of Transylvania (strongly criticized by von Born) through pieces of antiquarianism to studies dedicated to fighting famine by crop-rotation and turning familiar crops to new uses. ${ }^{134}$ Yet, the delegation of Hell as a dynamic and promising, young but already widely experienced man of science to peripheral Cluj was meant to give a boost to existing local initiatives in his fields of expertise. The first professor there to devote attention to astronomy was Miklós Jánossi (1701-41), active in Cluj in the mid-173os, possibly also engaging in observations from his own domicile in the convent, although astronomy appears as a matter of applied mathematics, not empirical measurement, in his 1737 textbook on trigonometry. ${ }^{135}$ A significant element of Hell's commission was apparently to redress this situation and supervise the construction of a new building of the college with an observatory, ${ }^{136}$ which was to be the fourth one run by Jesuits in the Austrian province after Vienna, Graz, and Trnava (also still a project in progress).

In fact, throughout the time Hell spent in Cluj, whatever observations he carried out there seem to have been done, similarly to Jánossi, from his home, ${ }^{137}$ and it is not clear exactly what preparations for a real observatory were really

133 On Jesuit mathematics and astronomy in China, see Catherine Jami, The Emperor's New Mathematics: Western Learning and Imperial Authority during the Kangxi Reign (16621722) (Oxford: Oxford University Press, 2011); for the development of the parallel with Transylvania, see Shore, Jesuits and the Politics of Religious Pluralism, 157-58.

134 http://jezsuita.hu/nevtar/frivaldszky-janos/ (accessed April 12, 2019).

135 László Heinrich, Az első kolozsvári csillagda (Bucharest: Kriterion, 1978), 24-27; http://jezsuita.hu/nevtar/janossi-miklos/ (accessed April 12, 2019). A collaborator of Jánossi in Cluj in 1737 was Mihály Lipsicz (1703-65) (http://jezsuita.hu/nevtar/lipsicz-mihaly-ii/ [accessed April 12, 2019]), who later, in the early 1740s, may have taught Weiss in Trnava and published Hungaria coelestis astronomiae et chronologam in synopsi complentes (Košice, 1741), a "baroque fusion of science and triumphalist history." Cf. Shore, Jesuits and the Politics of Religious Pluralism, 164 .

136 No actual instruction to Hell in this sense is extant, but (considerably later) references in Hell's own work and correspondence, as well as the posterior accounts of his life in Schlichtegroll, von Triesnecker, and Döbrentei are unanimous about the chief purpose of his appointment in Cluj.

137 Gábor Döbrentei, “Gróf Batthyány Ignác," Erdélyi Muzéum 2 (1815): 3-18, here 5. 
executed before he left for Vienna in 1755 . According to some of the literature, the new building, including the observatory, was completed around 1759 , and on an engraving from that year the building with a small tower is indeed visible. ${ }^{138}$ In various further sources, two of Hell's successors as professors of mathematics in Cluj, Matthias Geiger (1720-180o) and Miklós Benkő (1723-1801), are described as prof[essor] mathes[eos], praef[ectus] Mus[aei] Mathem [athici] et Spec[ulae] astron[omicae] (professor of mathematics, director of the mathematical museum [i.e., laboratory] and the astronomical observatory) in the periods $1755^{-57}$ and $175^{-62}$ respectively. ${ }^{139}$ However, in the last year of his Cluj appointment, Hell's titles already also included that of praefectus [...] spec. mathematicae, although at that time there was as yet certainly no specula at all. The Cluj observatory is not mentioned in the numerous works of Lalande or Johann III Bernoulli (1744-1807) that provide Europe-wide surveys of contemporary astronomy, ${ }^{140}$ let alone in Hell's Ephemerides. Over two decades after leaving Cluj, Hell provided this account in a letter to Bernoulli:

A fourth observatory, the construction of which was begun by me in Claudiopolis [Cluj] in Transylvania in the year 1753-I had laid down its very stable foundations by the year 1755 , when I was called to Viennahas remained unfinished until now. As of the year 1773, work on this building was about to be continued and brought to an end, if it were not for that fatal dissolution of my order, which brought this task in disarray. ${ }^{141}$ I had in fact an astronomer there, a father of our Society by the name Hartmann, professor of physics, whom I had furnished with a mobile,

138 Heinrich, Az első kolozsvári csillagda, 47.

139 Fischer, "Jesuiten-Mathematiker in der Deutschen Assistenz," 170; http://jezsuita.hu/ nevtar/geiger-matyas/; http://jezsuita.hu/nevtar/benko-miklos/ (accessed April 12, 2019).

140 See, e.g., Lalande, Astronomie, 2nd ed., vols. 1-2 ( Paris: Veuve Desaint, 1771); Lalande, Astronomie, 3rd ed., vols. 1-3 (Paris: Veuve Desaint, 1792); Johann III Bernoulli, Receuil pour les astronomes, vols. 1-3 (Berlin: l'Auteur, 1771-76); Bernoulli, Lettres astronomiques où l'on donne une idée de l'état actuel de l'astronomie pratique dans plusieurs villes de l'Europe (Berlin: l'Auteur, 1771); Bernoulli, Lettres sur différens sujets, écrites pendant le cours d'un voyage par l'Allemagne, la Suisse, la France méridionale et l'Italie, 3 vols. (Berlin: G.J. Decker, 1777-79).

141 As a matter of fact, the dissolution of the Society of Jesus heavily affected the Cluj academy. It was to be a secular university, with faculties of law and medicine added to philosophy and theology faculties, under the new name of Collegium Regium Theresianum Claudiopolitanum, where ex-Jesuits were retained, but leading roles were assigned to the Piarists (who had hitherto played little role in education in Transylvania). In 1784, Joseph II applied the "one country, one university" principle (already implicit in the Ratio educationis of 1777) by regarding-for this purpose-Hungary and Transylvania as a single country, and relegated the Cluj institution to the status of Lyceum Regium Academicum. 
three-foot quadrant, a pendulum clock, and a five-foot Newtonian telescope. [By the time of the suppression of the Society], I had already received from him several observations aimed at establishing the longitude and latitude of this observatory. ${ }^{142}$

The Cluj interlocutor mentioned by Hell must have been Ferdinand Hartmann (dates unknown), native of Sibiu (Nagyszeben, Cibinium/Hermannopolis, Hermannstadt), a Saxon town in far southeastern Transylvania. Hartmann entered the Society of Jesus in 1753 and served as a professor of geometry and "practical geography" (that is, geodesy) in Trnava in 1768-69, and as a professor of mathematics (1770-71) and experimental physics (1772-73) in Cluj. ${ }^{143}$ If, according to the letter to Bernoulli, Hartmann carried out observations from a still "unfinished" building, another twelve years later Hell reported that the foundations (fundamenta) he had been able to lay "still to this day lie hidden underground." 144 Whatever stage of completion the building ever reached, it fell victim to the fire of 1798 that ravaged extensive parts of Cluj, though some of the astronomical equipment could be saved for the new observatory, which was erected by 1805.145

The focus of Hell's recorded activities while in Cluj was not astronomy. He undertook experiments in electricity ${ }^{146}$ - in a characteristically eighteenthcentury fashion, combining a fascination with the field and an avid interest in magnetism ${ }^{147}$ - in the Museum Mathematicum, lectured as a professor of mathematics, preached in German and "Slavic," and extended pastoral care for military personnel. Unfortunately, his sermons, which may have allowed a glimpse of his religious views, are not extant. The electrical experiments,

142 Hell to Bernoulli III, Vienna, February 15, 1777. Universitätsbibliothek Basel (hereafter: Uвв), LIag64. Some letters at the end of each line are missing due to the binding. These are supplied in brackets.

143 Fischer, "Jesuiten-Mathematiker in der Deutschen Assistenz," 170. According to Heinrich, Az első kolozsvári csillagda, 49 (where it is also inaccurately claimed that Hartmann was Hell's immediate successor and held the position until 1769), it was József Mártonffy (1746-180o; http://jezsuita.hu/nevtar/martonffy-jozsef/ [accessed April 12, 2019]), future bishop of Alba Iulia (Gyulafehérvár) and a student of mathematics in Vienna in 1771-72 (presumably associated with Hell), who assisted Hartmann in obtaining instruments.

144 Hell to Bugge, Vienna, July 24, 1789. Pinzger, Hell Miksa, 2:154-55.

145 Heinrich, $A z$ első kolozsvári csillagda, 51-52.

146 He may have been inspired also in this by Franz, who used to perform electrical experiments in the Museum Mathematicum and published a Dissertatio de natura electrica [Treatise on the nature of electricity (1751)].

147 John L. Heilbron, Electricity in the 17th and 18th Centuries: A Study in Early Modern Physics (New York: Dover, 1979). 
however, bear some relation to a slender German-language book by Hell on the useful applications of artificial steel magnets, Anleitung zum nützlichen Gebrauch der künstlichen Stahl-Magneten (Introduction to the useful application of artificial steel magnets), first published in Vienna in 1762 , and then again in Graz in 1770. The bulk of this richly illustrated, fifty-page booklet is devoted to explaining how pieces of steel in various forms and sizes may be applied with the strongest magnetic force possible.

Hell's interest in magnetism will be dealt with in more detail in Chapter 8, in the context of his important engagement and controversy with Franz Anton Mesmer (1734-1815) following the latter's presentation of his Dissertatio physico-medica de planetarum influxu (Physico-medical dissertation on the influence of the planets) to the Viennese medical faculty in 1766 . A few aspects are worth stressing here. First, after a short historical account of the variegated uses of the magnetic needle - to which, in Hell's presentation, Europe owes all the riches of the Americas, easy access to fields of precious metals, as well as many other practical and scientific benefits - and a summary of eighteenthcentury inquiry into the subject, Hell records that the new type of artificial magnet had been quite unknown in "our lands" until recently: the first ones he had ever seen were

two finely polished little rods of English steel [...] brought to Transylvania from England by a certain professor of mathematics of the Reformed University [sic] in Cluj in the year 1754, exactly when I held the teaching position in mathematics at our university, and thanks to my acquaintance with the professor mentioned I had the honor of holding these two rods in my hands. ${ }^{148}$

Hell's Calvinist colleague was probably György Verestói (1698-1765). Verestói, who studied at the University of Franeker in the 1720s, was appointed as professor of philosophy and mathematics of the College of the Reformed Church in Cluj in 1728. He does not seem to have changed chairs till 1758, when he took over theology. In 176o, he was elected superintendent (bishop) of the Calvinist church in Transylvania. ${ }^{149}$ Verestói is mainly appreciated as an outstanding orator who, however, cultivated a strong interest in the natural sciences and

148 Maximilian Hell, Anleitung zum nützlichen Gebrauch der künstlichen Stahl-Magneten(Vienna: Ghelen, 1762), 12.

149 See István Török, "A kolozsvári collegium xvıı. századi tanárainak életrajza. (Verestói György 1728-1764 tanár s később püspök.)," Protestáns Közlöny 3, nos. 13-14 (1886): 122-23; 128-30; Török, A kolozsvári ev. ref. kollégium története (Cluj: Ev. Ref. Collegium, 1905), $3: 12-21$. 
their popularization, even by weaving topics from physics and astronomy in his applauded funeral orations. ${ }^{150}$ In any case, the complex interaction of Jesuits with their environment in Cluj thus included inter-denominational knowledge exchange. As Hell then goes on to explain, at that time

I already had a desire to do some research about this secret, but as for the time being I wanted to continue my pursuits in electricity, so that I could examine in these electric phenomena the Newtonian theory, and after various experiments I had come so far as to conclude that magnetic phenomena are nothing else than a certain degree of motion of electric matter; I postponed the exploration of the secrets of the artificial steel magnet, until I have fully developed my theory of electricity

- but then, though he had advanced considerably in this pursuit, his call to leave Cluj in the autumn of 1755 "interrupted all of my inquiries, as I had to dedicate myself fully to astronomy."151 It is noteworthy, however, that Hell's apparent enthusiasm about electricity also led him to assign to it a role in causing, besides magnetism, another phenomenon that was a long-term subject of his interests: northern lights. As he wrote a few years later, already as director of the Viennese university observatory, to his Trnava colleague Franz Weiss:

Honorable Father Colleague in Christ! Many thanks for the observation and elegant drawing of the aurora borealis that was observed in Tyrnavia [Trnava]. Your observation is in harmony with ours in most aspects, for here in Vienna, too, those tiny stripes as well as the ray that stretched out toward the north from the first pyramid were observed. However, since I personally observed the phenomenon somewhat later, I failed to see both the ray and those numerous stripes. Nor did I catch sight of those electric bundles to the left of the two northern rays because there was too much moisture in the atmosphere. I did observe, however, the three major beams. As for the cloud above the rays, I for my part could not distinguish it from here, but because this phenomenon is an electric phenomenon, I told my guests during the observation itself that there was bound to be

150 Katalin Németh S., "Magyar orátor a XvinI. században: Verestói György," Irodalomtörténet 73, no. 4 (1984): 877-80; Farkas Wellmann Éva, Irodalom és közönsége a XVIII. században: Verestói György munkássága (Budapest: Gondolat Kiadó, 2013); Réka Lengyel, "A világosság a tudomány': A felvilágosodás mint módszer Verestói György halotti beszédben," in A felvilágosodás előzményei Erdélyben és Magyarországon (1650-1750), ed. Mihály Balázs and István Bartók (Szeged: SzTe Magyar Irodalmi Tanszék, 2016), 315-27, here 321-25.

151 Hell, Anleitung, 13. 
a sort of cloud above the major rays, or at least some [accumulation of] thicker air that held a higher or lesser degree of electricity than the mountaintops of our Earth, from where it was capable of eliciting these rays. It filled me with joy that this cloud, which I had seen only in my imagination, was in fact spotted in Tyrnavia [Trnava], [for] this cloud demonstrates wonderfully that this opinion of mine is true, that the aurora borealis is an electric phenomenon. ${ }^{152}$

Hell was later to discard this opinion and develop another theory on the aurora, based on his experiences in Norway.

Besides the interaction with his local Calvinist counterpart, Hell's preoccupation with "useful applications" deserves attention. As we shall see, it is also paramount in other works originating in the Cluj years. In the preface to the Anleitung, he writes:

The reasons that led me to conceive this treatise were the great benefits from the use of these magnets [...]; the same motivation has also obliged me to write it not in erudite Latin, but in the common vernacular of our lands; as I am writing here not for the learned, but only for the skillful mechanics of our lands, who construct the machines with which good, strong, and proper magnetic needles ought to be produced; so I hope that this work of my spare hours will be embraced by these craftsmen in the same spirit in which it was conceived, namely to serve the common good, which I finally want to urge my readers to turn to the greater glory of God. ${ }^{153}$

While strictly utilitarian ends are here smoothly integrated with the Jesuit striving of working — as the Society's motto says—ad maiorem Dei gloriam, Hell also makes a point of stressing that as far as the cognitive-methodological foundations of the claims advanced in the book are concerned, these are strictly empirical: "I have learned not from books, nor by oral instruction or otherwise from someone else, but from my own experiments alone." 154 We have no first-hand report about any of the experiments he carried out while in Cluj. Secondary evidence, deriving from the section on the electricity of bodies in

$15^{2}$ Hell to Weiss in Trnava, dated Vienna, April 1, 1761 (Vargha priv. In Pinzger, Hell Miksa, 2:187, this letter is wrongly dated April 1, 1766).

153 Hell, Anleitung, 5. For another forceful statement on the need, indeed the social responsibility, of seeking "useful applications" for scientific discoveries beyond the pleasure they cause to the discoverer, see Hell, Anleitung, 33 .

154 Hell, Anleitung, 4. 
the textbook Institutiones physicae (Introductions to physics [1756]) by the Trnava professor and later Trenčín rector András Jaszlinszky (1715-83), however, reports that the purview of Hell's work during the Cluj years not only included the possible uses of electricity and magnetism in healing and resulted in three (now lost) treatises on the subject but also the successful treatment of three elderly men against pain in the leg, dyspepsia, and some kind of tumor by electric sparks. ${ }^{155}$ As such, then, the later engagement with Mesmer has specific antecedents in Hell's Cluj activities.

The Cluj period also saw the publication of two textbooks by Hell, Varia compendia praxesque operationum arithmeticarum (Various introductions and exercises in arithmetic), ${ }^{156}$ and the first and only volume, dedicated to arithmetic and algebra, of a planned series entitled Elementa mathematica naturali philosophiae ancillantia (Basic mathematics for the aid of natural philosophy). ${ }^{157}$ In addition, he also composed a collection of exercises, published separately in Cluj as Exercitationes arithmeticae (Exercises in arithmetic) in 1755, and subsequently as an appendix to the Elementa. Hell thus became firmly involved in the response to the recently introduced requirement by the Viennese authorities, already mentioned, of supporting the reform of higher education by publishing standard textbooks to supplement and supersede students' lecture notes. Even though he soon left Transylvania and quit teaching mathematics for good, the Elementa was reissued several times, in both Poznań (Posen) and Vienna, but apparently never revised. Thus, in the third edition (Vienna, 1761), we read in the exercises:

A merchant in Cluj, selling a Cluj short ulna [or "ell," a measure of length] for the same price as a long ulna was bought in Vienna, wishes to know the profit percent. Since five Cluj ulnae equal four Viennese, this means that for every four Viennese ulnae there is a gain of one Cluj ulna. Accordingly, the sum should be stated thus $[\ldots] .{ }^{158}$

155 Andreas Jaszlinszky, Institutiones physicae (Trnava: Academia Societatis Jesu, 1756), 2:189. Cf. Heinrich, A kolozsvári csillagda, 37. Jaszlinszky was one of the scholars involved in the intense engagement with Cartesianism and Newtonianism in Trnava in the 1750s. Cf. above, 62 n.69.

156 Virtually all accounts of Hell's life and career mention this work. However, we have been unable to locate it in any library.

157 Maximilian Hell, Elementa arithmeticae numericae, et literalis seu algebrae ad prefixam in scholis nostris normam concinnata (Vienna: Trattner, 1761 [1755]).

$15^{8}$ Hell, Elementa arithmeticae numericae, appendix, 35 . 
This is applied mathematics, adapted for a local audience. Practical applications permeate the book as a whole: the exercises in the appendix are specifically designed not merely for the use of the studious youth (ad usum privatum studiosae iuventutis) but contain questions of an economic nature for the use of citizens and merchants (Questionibus oeconomicis, \& ad usum Civilem ac Mercatorum applicatis declaratae). ${ }^{159}$ The same ends are also apparent from a section describing and comparing various measurements and currencies from around Europe. ${ }^{160}$ Elsewhere, in a collection of thirty-nine questions for the public examination of two of Hell's students, the task of the candidates is to calculate Cluj's distance from Rome on the basis of data according to which a peregrinus, who made half the journey on horseback and a quarter of it on foot, covered altogether 126 miles (the solution given both by simple equation and by proportion). ${ }^{161}$ The utilitarian inspiration and aims of the Elementa is emphasized in the author's preface in a way that combines religious commitments specific to the Society of Jesus with secular ones. Hell confesses there to be aspiring to serve "the glory of God and the progress of the benefit of the fatherland," and the former aspect is repeated once again in his introduction to the supplement of exercises for further study at home, bidding his students farewell in the wish that they "add to the Greater glory of God through [them] selves and [their] efforts." 162 Ad maiorem Deigloriam, the motto of the Society of Jesus, with its missionary implications, thus found its way to Hell's 1755 mathematics textbook in unison with the expression of his patriotic loyalties.

It is against the whole of the background and trajectory outlined in this chapter that Hell's notion of patria - one in harmony with his allegiance to the Jesuit order-needs to be appreciated. Hell as a patriot belonged to the community of free and educated, Hungarus denizens of the Kingdom of Hungary, the natio hungarica: a socially highly variegated group dominated by the nobility, but sharing more widely in a political heritage focused on the veneration of royal dynasties and a stock of ancient customs and statutes (re-conceptualized

159 Hell, Elementa arithmeticae numericae, unpaginated.

16o Hell, Elementa arithmeticae numericae, 87-93.

161 Maximilian Hell [Maximilianus Höll], Materia tentaminis mathematici: Aula Academica S.J. Claudiopolitana, die 14 Mensis Julii 1755 . Cited in Heinrich, A kolozsvári csillagda, $3^{2-33 .}$

162 Hell, Elementa arithmeticae numericae, praefatio, unpaginated, and appendix, unpaginated; see also the Scholion 362: "The following courses of mathematics are recommended: [...] If beginners are to seek their basic knowledge of mathematics in those textbooks, I hope they will keep in mind the words of Paul the Evangelist, [whateveryou do], do all to the glory of God (1 Corinthians 4:31)." Hell, Elementa arithmeticae numericae, 230. Curiously, the reference to 1 Cor. 4:31 is a misprint for 1 Cor. 10:31. The gloriam DEI part, however, resonates clear enough. 
later in the century as a "constitution"), and a cultural heritage that was multiethnic, multi-confessional, and expressed chiefly in the Latin language (also the language of public affairs and political communication until 1844). "Lingua Slavus, natione Hungarus, eruditione Germanus"-I am Slav (Slovak) by (mother) tongue, Hungarus by nation, German by erudition: this is how the prototype of this kind of "patriot," the Lutheran polymath Matej/Mátyás/Matthias Bel/Bél (1684-1749), explained his identity. The supranational Hungarus consciousness, soon to be challenged by the rise of linguistic nationalism, was compatible both with the cosmopolitanism of the Enlightenment-in a way, given its strong anchorage in the home-grown traditions of secondary and higher education, the Hungarus elite also understood itself as a local Republic of Letters marked by emulation as well as tolerance-and the global horizons of the Society of Jesus. ${ }^{163}$ As it was also conducive to the cultivation of dialogue and the maintenance of equilibrium among diverse stakeholders and leading voices in the kingdom, nor was Hungarus patriotism antithetical to the views of the architects of Theresan reform in the imperial capital.

Hell's pursuit of the progress of his "fatherland" and the glory of God in the periphery of the Austrian province barely lasted three years. Before the $1755^{-}$ $5^{6}$ academic year had started, he was called back to its center, but this time principally as a servant of the state rather than God: he was appointed as imperial and royal astronomer at the helm of the newly established Viennese university observatory.

163 Some scholars have attributed the rise of the concept of Hungarus to the philosophy of history worked out by Hungarian Jesuits and, more generally, to the "national baroque"; others to the patriotism of the Slovak and German Lutheran professionals; still others stress that, from the mid-eighteenth century, the Enlightenment notion of humanity (Humanität/Menschenliebe) was crucial to it. See Gyula Szekfü, Magyar történet (Budapest: Királyi Magyar Egyetemi Nyomda, 1935), 4:378-79; Andor Tarnai, Extra Hungariam non est vita [...] (Egy szállóige történetéhez) (Budapest: Akadémiai Kiadó, 1969); http:// mek.niif.hu/05400/05453/05453.htm (accessed April 12, 2019), esp. 99-100; Moritz Csáky, "Die Hungarus-Konzeption," in Ungarn und Österreich unter Maria Theresia und Joseph II, ed. Anna Maria Drabek, Richard G. Plaschka, and Adam Wandruszka (Vienna: Verlag der Österreichischen Akademie der Wissenschaften, 1982), 71-89; István Fried, "A hungarustudat kérdőjelei," in A közép-európai szöveguniverzum (Budapest: Lucidus, 2002), 47-68; Ambrus Miskolczy, "A 'hungarus alternatíva': Példák és ellenpéldák," Regio 20, no. 2 (2009): 3-46; Miskolczy, "Hungarus Consciousness' in the Age of Early Nationalism," in Latin at the Crossroads of Identity: The Evolution of Linguistic Identity in the Kingdom of Hungary, ed. Gábor Almási and Lav Šubarić (Leiden: Brill, 2015), 64-94. 